\title{
Endocannabinoid Signaling Dynamics Probed with Optical Tools
}

\author{
Thomas Heinbockel, ${ }^{1,2 *}$ Darrin H. Brager, ${ }^{1 \star}$ Christian G. Reich, ${ }^{1}$ Jun Zhao, ${ }^{3}$ Sukumaran Muralidharan, ${ }^{3}$ \\ Bradley E. Alger, ${ }^{1,2}$ and Joseph P. Y. Kao ${ }^{1,2,3}$ \\ ${ }^{1}$ Department of Physiology, ${ }^{2}$ Program in Neuroscience, University of Maryland School of Medicine, and ${ }^{3}$ Medical Biotechnology Center, University of \\ Maryland Biotechnology Institute, Baltimore, Maryland 21201
}

\begin{abstract}
Intercellular signaling dynamics critically influence the functional roles that the signals can play. Small lipids are synthesized and released from neurons, acting as intercellular signals in regulating neurotransmitter release, modulating ion channels on target cells, and modifying synaptic plasticity. The repertoire of biological effects of lipids such as endocannabinoids (eCBs) is rapidly expanding, yet lipid signaling dynamics have not been studied. The eCB system constitutes a powerful tool for bioassaying the dynamics of lipid signaling. The eCBs are synthesized in, and released from, postsynaptic somatodendritic domains that are readily accessible to whole-cell patch electrodes. The dramatic effects of these lipid signals are detected electrophysiologically as CB1-dependent alterations in conventional synaptic transmission, which therefore serve as a sensitive reporter of eCB actions. We used electrophysiological recording, photolytic release of caged glutamate and a newly developed caged AEA (anandamide), together with rapid $\left[\mathrm{Ca}^{2+}\right]_{\mathrm{i}}$ measurements, to investigate the dynamics of retrograde eCB signaling between CA1 pyramidal cells and GABAergic synapses in rat hippocampus in vitro. We show that, at $22^{\circ} \mathrm{C}, \mathrm{eCB}$ synthesis and release must occur within $75-190 \mathrm{~ms}$ after the initiating stimulus, almost an order of magnitude faster than previously thought. At $37^{\circ} \mathrm{C}$, the time could be $<50 \mathrm{~ms}$. Activation of $\mathrm{CB} 1$ and downstream processes constitute a significant fraction of the total delay and are identified as major rate-limiting steps in retrograde signaling. Our findings imply that lipid messenger dynamics are comparable with those of metabotropic neurotransmitters and can modulate neuronal interactions on a similarly fast time scale.
\end{abstract}

Key words: anandamide; metabotropic glutamate; calcium; photolysis; GABA; endocannabinoid

\section{Introduction}

The dynamic properties of intercellular signaling systems greatly influence the ways in which cells affect each other. Moreover, signaling dynamics impose critical constraints on models of the underlying signaling mechanisms. Small lipid molecules, including platelet-activating factor, arachidonic acid, prostaglandins (for review, see Bazan, 2003), and endocannabinoids (eCBs) (for review, see Alger, 2002; Freund et al., 2003), constitute a major class of intercellular messengers. However, there is little information on the dynamics of lipid signal mobilization. This reflects partly the difficulty in capturing and measuring tiny quantities of

Received May 23, 2005; revised Aug. 29, 2005; accepted Aug. 30, 2005.

This work was supported by Public Health Service Grants R01 NS30219 and R01 DA14625 (B.E.A.) and GM56481 (J.P.Y.K.) and a University of Maryland School of Medicine Bressler Fund Award (T.H.). C.G.R. was supported by National Institutes of Health Postdoctoral Training Grant T32 NS07375. We thank Drs. Scott Thompson and Masako Isokawa for allowing us to use their hippocampal slice cultures. We thank Catherine Ledent for giving us the CB1 knock-out mice. D.H.B., T.H., and C.G.R. conducted the physiological studies in B.E.A.'s laboratory. J.Z. and S.M. synthesized and tested the caged compounds in J.P.Y.K.'s laboratory.

*T.H. and D.H.B. contributed equally to this work.

Correspondence should be addressed to Dr. Bradley E. Alger, Department Physiology, Program in Neuroscience, University of Maryland School of Medicine, 655 West Baltimore Street, Baltimore, MD 21201. E-mail: balger@umaryland.edu.

T. Heinbockel's present address: Department of Anatomy, Howard University College of Medicine, Washington, DC 20059.

D. H. Brager's present address: Center for Learning and Memory, University of Texas at Austin, Austin, TX 78712-0132.

D01:10.1523/JNEUROSCI.2078-05.2005

Copyright $\odot 2005$ Society for Neuroscience $\quad$ 0270-6474/05/259449-11\$15.00/0 lipid messengers, and partly the absence of a well established model system that offers sufficient experimental control over the lipid release process. Lipid signals are not stored in vesicles but are generated from membrane-bound precursors by enzymatic activity initiated in response to cellular stimuli, such as a rise in $\left[\mathrm{Ca}^{2+}\right]_{\mathrm{i}}$, or the activation of biochemical cascades. Lipids are released across the plasma membrane. Rapid kinetic measurements have not been the focus of previous investigations, and the maximum speed with which lipid messengers can be produced is essentially unknown.

Recently, eCBs have emerged as putative retrograde intercellular messengers in the mammalian CNS (Kreitzer and Regehr, 2001a,b; Ohno-Shosaku et al., 2001; Wilson and Nicoll, 2001). The two major eCBs, arachidonoylethanolamide [anandamide (AEA) ] and 2-arachidonoyl glycerol (2-AG), both derivatives of arachidonic acid (Iversen, 2003) (for review, see Freund et al., 2003) are agonists at the G-protein-coupled receptor (GPCR), $\mathrm{CB} 1$. Both AEA and 2-AG can be released from postsynaptic principal cell somata and dendrites, and their release is stimulated by a marked rise in $\left[\mathrm{Ca}^{2+}\right]_{\mathrm{i}}$. Release of eCB can also be caused by activation of GPCRs including dopamine (Giuffrida et al., 1999), metabotropic glutamate (Maejima et al., 2001; Varma et al., 2001), or muscarinic acetylcholine receptors (Kim et al., 2002; Ohno-Shosaku et al., 2003) and can persist for many minutes. The metabotropic glutamate receptor (mGluR)- and muscarinic acetylcholine receptor-dependent pathways are not asso- 
ciated with a marked rise in $\left[\mathrm{Ca}^{2+}\right]_{\mathrm{i}}$ (Maejima et al., 2001; Kim et al., 2002), and can be triggered even in the presence of high intracellular concentrations of $\mathrm{Ca}^{2+}$ chelators, although they may nevertheless be sensitive to ambient $\left[\mathrm{Ca}^{2+}\right]_{\mathrm{i}}$ (Hashimotodani et al., 2005). Whether these separate pathways operate on the same time scales is not known. The kinetic properties of the eCBmediated responses will critically constrain the candidate biochemical pathways.

The eCB system constitutes a powerful tool for bioassaying the dynamics of lipid signaling. The eCBs are synthesized in, and released from, postsynaptic somatodendritic domains that are readily accessible to whole-cell patch electrodes. The dramatic effects of these lipid signals are detected electrophysiologically as $\mathrm{CB} 1$-dependent alterations in conventional synaptic transmission, which therefore provide a sensitive means of bioassaying $\mathrm{eCB}$ actions. Indeed, the first estimates of the speed of intercellular lipid signaling were provided by the study of depolarizationinduced suppression of inhibition (DSI) (Pitler and Alger, 1994; Wilson et al., 2001). In the present study, by combining wholecell voltage-clamp, $\left[\mathrm{Ca}^{2+}\right]_{\mathrm{i}}$ measurements, and photorelease of caged glutamate and a novel, caged AEA, we investigated the dynamics of eCB signaling in hippocampal slices.

\section{Materials and Methods}

\section{Preparation of acute hippocampal slices}

Hippocampal slices were obtained mainly from 4- to 6-week-old male Sprague Dawley rats. In some experiments, as noted, mice (25-40 g) in which the CB1 gene had been inactivated (Ledent et al., 1999) were used. All experiments were performed in accordance with the guidelines set forth by the Institutional Animal Care and Use Committee of the University of Maryland School of Medicine. After the animals were deeply anesthetized with halothane and decapitated, the hippocampi were removed and sectioned into $400-\mu \mathrm{m}$-thick slices in ice-cold saline using a vibratome (Technical Products International, St. Louis, MO). The slices were maintained at room temperature in an interface holding chamber in a humidified atmosphere saturated with $95 \% \mathrm{O}_{2} / 5 \% \mathrm{CO}_{2}$ for at least an hour before being transferred to the submersion-type chamber (Nicoll and Alger, 1981) where the experiments were performed at $30 \pm 1^{\circ} \mathrm{C}$.

\section{Preparation of organotypic slice cultures}

Organotypic hippocampal slice cultures were prepared either as rollertube cultures (Gähwiler et al., 1998) or as interface cultures on semiporous membranes (Stoppini et al., 1991). Hippocampi were dissected from 5- or 6-d-old $\mathrm{CO}_{2}$-anesthetized rat or $\mathrm{CB} 1^{-1-}$ mouse pups, and cut into 375- $\mu \mathrm{m}$-thick transverse slices using a McIlwain tissue chopper (Brinkmann Instruments, Westbury, NY). Slices were attached to polylysine-coated glass coverslips in $20 \mu \mathrm{l}$ of chicken plasma coagulated with thrombin. Coverslips were placed into culture tubes with $750 \mu \mathrm{l}$ of serum-containing medium and incubated in a roller-drum at $36^{\circ} \mathrm{C}$. Alternatively, slices were placed on porous, transparent membranes attached to the bottom of a round polystyrene chamber and kept in six-well tissue culture plates. Organotypic slices prepared with the roller-tube method were $\mathrm{x}$-irradiated at the time of explantation and treated overnight with antimitotics to reduce the proliferation of glial cells. Slice cultures were held in a $36^{\circ} \mathrm{C}$ incubator with $5 \% \mathrm{CO}_{2}$ and maintained in vitro for $>14 \mathrm{~d}$ before performing experiments to allow for synaptic maturation.

Cultures were perfused at $\sim 1 \mathrm{ml} / \mathrm{min}$ with control saline containing the following (in mM): $137 \mathrm{NaCl}, 2.8 \mathrm{KCl}, 2.5 \mathrm{CaCl}_{2}, 2.5 \mathrm{MgCl}_{2}, 23.2$ $\mathrm{NaHCO}_{3}, 0.4 \mathrm{NaH}_{2} \mathrm{PO}_{4}, \mathrm{pH}$ to 7.2 with HEPES, and 5.6 glucose at room temperature $\left(20-22^{\circ} \mathrm{C}\right)$ in a closed recirculating system. Caged glutamate $(\mathrm{Ncm}-\mathrm{Glu})(1 \mathrm{~mm})$ or caged AEA $(200 \mu \mathrm{M})$ was included in the extracellular saline as indicated in the relevant text or figure.

\section{Electrophysiology}

Current-clamp recordings from CA1 pyramidal cells in acute slices were obtained with sharp, glass microelectrodes $(50-150 \mathrm{M} \Omega$ ) filled with $3 \mathrm{M}$
$\mathrm{KCl}$. Reliable spontaneous IPSP activity (seen in $\sim 80 \%$ of all recorded cells) was observed after a 5-20 min bath application of carbachol (CCh), 1,2,3,4-tetrahydro-6-nitro-2,3-dioxo-benzo[f] quinoxaline-7-

sulfonamide (NBQX), and DL-2-amino-5-phosphonopentanoic acid (AP5). We refer to this IPSC activity as "spontaneous" as is conventional, because it is persistent and does not require additional stimulation to evoke it. "Theta burst" trains of action potentials, each comprising five action potentials elicited by positive, constant-current pulses (each 5 or $10 \mathrm{~ms}$ in duration) were delivered via the microelectrode at $50 \mathrm{~Hz}$. Repetitive bursts were delivered at $200 \mathrm{~ms}$ intervals (i.e., at $5 \mathrm{~Hz}$ ) to elicit DSI. Signals were digitized at $5 \mathrm{kHz}$ with an analog-to-digital interface (Digidata 1200A; Molecular Devices, Palo Alto, CA) and analyzed with pClamp 9.0 software (Molecular Devices).

The intracellular whole-cell patch pipette solution used in slicecultured cells contained the following (in mM): $90 \mathrm{CsCH}_{3} \mathrm{SO}_{3}, 50 \mathrm{CsCl}, 1$ $\mathrm{MgCl}_{2}$, 2 Mg-ATP, 0.3 Tris-GTP, $0.2 \mathrm{Cs}_{4}$ BAPTA, 10 HEPES, and 5 QX314 (lidocaine $\mathrm{N}$-ethyl bromide), $\mathrm{pH} 7.20$ with $\mathrm{CsOH}$, and $295 \mathrm{mOsm}$. In some experiments, $90 \mathrm{~mm} \mathrm{CsCH}_{3} \mathrm{SO}_{3}$ was replaced by $20 \mathrm{~mm} \mathrm{Cs}_{4}$ BAPTA (Invitrogen, Eugene, OR) to block rises in $\left[\mathrm{Ca}^{2+}\right]_{\mathrm{i}}$. Seal resistance was routinely $>1 \mathrm{G} \Omega$. Recordings were made with an Axoclamp 2B amplifier and collected through a Digidata-1200A Interface (Molecular Devices). Analog signals were recorded, digitized at $5 \mathrm{kHz}$, low-pass filtered at 2 $\mathrm{kHz}$, and subsequently analyzed using Clampfit (Clampfit 9; Molecular Devices) and Mini Analysis Program (version 6.0.1; Synaptosoft, Decatur, GA).

Monosynaptic evoked IPSCs (eIPSCs) were elicited by $100-\mu$ s-long extracellular stimulus pulses $(150-250 \mu \mathrm{A})$ delivered with concentric bipolar stimulating electrodes (David Kopf Instruments, Tujunga, CA), or with a low resistance (1-2 $M \Omega$ ) patch pipette filled with extracellular saline, placed in the stratum oriens between CA3 and CA1, 0.5-1 mm apart from the recording site. To isolate monosynaptic eIPSCs, ionotropic glutamate receptor blockers NBQX $(10 \mu \mathrm{M})$ and AP5 (50 $\mu \mathrm{M})$ were present in the bath solution throughout all experiments. In experiments that focused on spontaneous IPSPs (sIPSPs) or spontaneous IPSCs (sIPSCs), CCh (500 nM or $5 \mu \mathrm{M}$, as noted) was added to the bathing solution. The lower concentration of $\mathrm{CCh}$ was used in cultured slices because they are prone to generating paroxysmal sIPSC activity in $5 \mu \mathrm{M}$ $\mathrm{CCh}$, which was used for acute slices. Water-based stock solutions of CCh, 2S-2-amino-2-(1S,2S-2-carboxycycloprop-1-yl)-3-(xanth-9-yl)propanoic acid (LY341495) (Tocris, Ballwin, MO), or DMSO-based stock solutions of $\mathrm{N}$-(piperidin-1-yl)-5-(4-iodophenyl)-1-(2,4-dichlorophenyl)-4methyl-1 $H$-pyrazole-3-carboxamide (AM251) (Tocris), and $R$ - $(+)-(2,3-$ dihydro-5-methyl-3-[(4-morpholinyl)methyl]pyrrolo[1,2,3-de]-1,4benzoxazin-6-yl)-(1-naphthalenyl)methanone monomethanesulfonate (WIN55212-2) (Tocris) were added to the bath solution and perfused into the recording chamber when needed. The final concentration of DMSO was $0.01 \%(\mathrm{v} / \mathrm{v})$. All other chemicals were purchased from Sigma-Aldrich (St. Louis, MO).

\section{$\mathrm{Ca}^{2+}$ imaging}

$\mathrm{Ca}^{2+}$-dependent fluorescence of fluo-3 (50 $\mu \mathrm{M}$ in the whole-cell pipette) was collected by a photomultiplier tube (PMT) (H5783; Hamamatsu, Hamamatsu City, Japan) and recorded concurrently with IPSCs. A filter set suitable for fluo-3 (Chroma 41025; exciter HQ470/40×; emitter HQ515/30m; dichroic Q495LP) was used in conjunction with a Nikon (Melville, NY) Eclipse 600 upright microscope ( $40 \times 0.8$ numerical aperture objective). The output of the PMT was low-pass filtered at $2 \mathrm{kHz}$ (Frequency Devices, Haverhill, MA), digitized at $5 \mathrm{kHz}$ (Digidata 1322; Molecular Devices), and displayed by pClamp9 (Molecular Devices) using Clampex. Trials were analyzed off-line using Origin software (OriginPro 7; OriginLab, Northampton, MA). Data from three to four trials were averaged. To correct fluorescence baseline drift caused by gradual photobleaching, two $3 \mathrm{~s}$ segments (immediately before photolytic or electrical stimulation and at the end of each fluorescence record) were fit by a single exponential, which was used as the baseline. Details of the optics used for focal photolysis are given below.

Chemical synthesis and characterization of caged AEA

General. Unless otherwise specified, reagents and solvents of American Chemical Society grade or better were purchased from Sigma-Aldrich, 
Advanced ChemTech (Louisville, KY), Fisher Scientific (Pittsburgh, PA), or VWR International (West Chester, PA), and were used without additional purification. UV-visible absorption spectra were recorded on a Cary 300 Bio spectrophotometer (Varian Instruments, Walnut Creek, $\mathrm{CA})$. Proton nuclear magnetic resonance (NMR) spectra were recorded on either a $300 \mathrm{MHz}$ (QE-300; General Electric, Fairfield, CT) or a 500 $\mathrm{MHz}$ spectrometer (INOVA 500; Varian Instruments) and were referenced to tetramethylsilane $(\delta=0)$. For reporting NMR spectra, the following descriptors are used: singlet $(\mathrm{s})$, doublet $(\mathrm{d})$, triplet $(\mathrm{t})$, quartet (q), multiplet (m), and broad (br); underlining within a molecular fragment indicates the group of protons to which a spectral resonance is assigned. HPLC was performed on a system fitted with a photodiode array detector (model 600; Waters Associates, Milford, MA). Fast-atom bombardment (FAB) high-resolution mass spectrometry (HRMS) was performed at the analytical facility in the Department of Biochemistry at Michigan State University (East Lansing, MI).

Ethyl 2-(3-formyl-4-nitrophenoxy)acetate (1). Under dry $\mathrm{N}_{2}$, anhydrous $\mathrm{K}_{2} \mathrm{CO}_{3}(2.90 \mathrm{~g} ; 21 \mathrm{mmol})$ was added to a solution of 5-hydroxy-2nitrobenzaldehyde $(5.01 \mathrm{~g} ; 30 \mathrm{mmol})$ and ethyl bromoacetate $(6.01 \mathrm{~g} ; 36$ $\mathrm{mmol})$ in dry acetonitrile $(50 \mathrm{ml})$. The reaction mixture was stirred at room temperature for $24 \mathrm{~h}$. After filtration to remove solids, the filtrate was concentrated and purified by column chromatography on silica gel (hexane/ethyl acetate, 95:5 $\rightarrow$ 80:20) to yield compound 1 (all compounds are numbered as in Fig. $1 A$ ) as yellow needles [6.84 $\mathrm{g}(90 \%)$; melting point (m.p.), $\left.58-59^{\circ} \mathrm{C}\right] .{ }^{1} \mathrm{H}$ NMR $(300 \mathrm{MHz}) \delta$ was as follows: $1.32\left(\mathrm{t}, 3 \mathrm{H}, \mathrm{CH}_{3}\right), 4.30\left(\mathrm{q}, 2 \mathrm{H}, \mathrm{CH}_{2} \mathrm{CH}_{3}\right), 4.78\left(\mathrm{~s}, 2 \mathrm{H}, \mathrm{OCH}_{2} \mathrm{CO}\right), 7.18(\mathrm{~d}$, $1 \mathrm{H}, J=9.0 \mathrm{~Hz}$, aromatic, $\mathrm{H}-6), 7.31(\mathrm{~s}, 1 \mathrm{H}$, aromatic, $\mathrm{H}-2), 8.16(\mathrm{~d}, 1 \mathrm{H}$, $J=8.8 \mathrm{~Hz}$, aromatic, $\mathrm{H}-5)$, and $10.5(\mathrm{~s}, 1 \mathrm{H}, \mathrm{CHO})$.

(2-tert-Butoxyethyl)-(5-ethoxycarbonylmethoxy-2-nitrobenzyl)amine (2a). Starting material 1 (0.506 g; $2.0 \mathrm{mmol})$, (2-t-butoxyethyl)amine (0.281 g; $2.4 \mathrm{mmol}$; CSP Pharmaceuticals, San Diego, CA), and sodium acetate $(0.164 \mathrm{~g} ; 2.0 \mathrm{mmol})$ were added to 1,2 -dichloroethane $(10 \mathrm{ml})$. The mixture was stirred for $1 \mathrm{~h}$ under dry $\mathrm{N}_{2} . \mathrm{NaBH}\left(\mathrm{CH}_{3} \mathrm{CO}_{2}\right)_{3}(1.06 \mathrm{~g}$; $5 \mathrm{mmol}$ ) was then added in one portion and stirring was continued at room temperature overnight $(\sim 18 \mathrm{~h})$. The mixture was diluted with $\mathrm{CH}_{2} \mathrm{Cl}_{2}(20 \mathrm{ml})$, and the reaction was quenched with $10 \mathrm{ml}$ of saturated $\mathrm{NaHCO}_{3}$ solution. The organic phase was separated, washed with saturated $\mathrm{NaHCO}_{3}(10 \mathrm{ml}$; two times) and brine $(15 \mathrm{ml})$, and dried over anhydrous $\mathrm{MgSO}_{4}$. Flash chromatography on silica gel (hexane/ethyl acetate, $90: 10 \rightarrow 65: 35: 1 \% \mathrm{Et}_{3} \mathrm{~N}$ ) yielded compound 2 as a pale yellow oil [0.465 g (65.6\%)]. ${ }^{1} \mathrm{H}$ NMR $(300 \mathrm{MHz}) \delta$ was as follows: $1.2(\mathrm{~s}, 9 \mathrm{H}$, $\left.\mathrm{C}\left(\mathrm{CH}_{3}\right)_{3}\right), 1.31\left(\mathrm{t}, 3 \mathrm{H}, \mathrm{CH}_{3}\right), 2.04(\mathrm{br} \mathrm{s}, 1 \mathrm{H}, \mathrm{NH}), 2.76\left(\mathrm{t}, 2 \mathrm{H}, \mathrm{CH}_{2} \mathrm{OBu}-\right.$ t), $3.49\left(\mathrm{t}, 2 \mathrm{H}, \mathrm{NCH}_{2} \mathrm{CH}_{2} \mathrm{O}\right), 4.14\left(\mathrm{~s}, 2 \mathrm{H}, \mathrm{CH}_{2} \mathrm{Ar}\right), 4.30(\mathrm{q}, 2 \mathrm{H}$, $\left.\mathrm{OCH}_{2} \mathrm{CH}_{3}\right), 4.72\left(\mathrm{~s}, 2 \mathrm{H}, \mathrm{OCH}_{2} \mathrm{CO}\right), 6.85(\mathrm{~d}, 1 \mathrm{H}, \mathrm{J}=8.8 \mathrm{~Hz}$, aromatic), $7.27\left(\mathrm{~s}, 1 \mathrm{H}\right.$, aromatic), and $8.10\left(\mathrm{~d}, 1 \mathrm{H}, J=9.0 \mathrm{~Hz}, \mathrm{H}\right.$ ortho to $\left.\mathrm{NO}_{2}\right)$.

$\mathrm{N}$-(2-tert-Butoxyethyl)-N-(5-ethoxycarbonylmethoxy-2-nitrobenzyl) arachidonoylamide ( $3 a$ ). To prepare arachidonoyl chloride, oxalyl chloride $(0.32 \mathrm{~g} ; 0.22 \mathrm{ml} ; 2.5 \mathrm{mmol})$ was added to a solution of arachidonic acid $(0.5 \mathrm{~g} ; 1.64 \mathrm{mmol})$ in anhydrous $\mathrm{CH}_{2} \mathrm{Cl}_{2}(15 \mathrm{ml})$; a drop of dry dimethylformamide (DMF) was added to initiate the reaction. The mixture was stirred at room temperature for $1 \mathrm{~h}$, and then evaporated under reduced pressure to yield an oily residue. To ensure complete removal of trapped $\mathrm{HCl}$ and residual oxalyl chloride, the residue was twice redissolved in dry $\mathrm{CH}_{2} \mathrm{Cl}_{2}(10 \mathrm{ml})$ and evaporated to dryness under reduced pressure. The final product was dissolved in dry $\mathrm{CH}_{2} \mathrm{Cl}_{2}$ to make $5.0 \mathrm{ml}$ of solution in a volumetric flask.

Under dry $\mathrm{N}_{2}$, arachidonoyl chloride solution in $\mathrm{CH}_{2} \mathrm{Cl}_{2}(4 \mathrm{ml} ; 1.3$ $\mathrm{mmol}$ ) was added dropwise by syringe to a solution of amine $2 \mathrm{a}(0.425 \mathrm{~g}$; $1.2 \mathrm{mmol})$ and $\mathrm{Et}_{3} \mathrm{~N}(0.243 \mathrm{~g} ; 0.334 \mathrm{ml} ; 2.4 \mathrm{mmol})$ in dry $\mathrm{CH}_{2} \mathrm{Cl}_{2}(10 \mathrm{ml})$. The resulting mixture was stirred at room temperature for $2 \mathrm{~h}$, during which the amine was completely converted to the amide, as verified by TLC on silica gel plates (hexane/EtOAc, 7:3). The reaction mixture was diluted with $\mathrm{CH}_{2} \mathrm{Cl}_{2}(20 \mathrm{ml})$, and saturated $\mathrm{NaHCO}_{3}$ solution $(10 \mathrm{ml})$ was added. The organic phase was separated, washed with saturated $\mathrm{NaHCO}_{3}(10 \mathrm{ml}$; two times) and brine $(15 \mathrm{ml})$, and dried over anhydrous $\mathrm{MgSO}_{4}$. Purification by flash chromatography on silica gel (hexane/ EtOAc, 95:5 $\rightarrow 85: 15)$ yielded a viscous yellow oil $[0.665 \mathrm{~g}(86.5 \%)] .{ }^{1} \mathrm{H}$ NMR $(300 \mathrm{MHz}) \delta$ was as follows: $0.88\left(\mathrm{t}, 3 \mathrm{H}, \mathrm{CH}_{3}\right.$ of aliphatic chain), $1.15\left(\mathrm{~s}, 9 \mathrm{H}, \mathrm{C}\left(\mathrm{CH}_{2}\right)_{3}\right), 1.30\left(\mathrm{~m}, 9 \mathrm{H}, 3 \times \mathrm{CH}_{2}+\mathrm{OCH}_{2} \mathrm{CH}_{3}\right), 1.72(\mathrm{~m}, 2 \mathrm{H}$,
$\left.\mathrm{CH}_{2}\right), 2.05\left(\mathrm{~m}, 3 \mathrm{H}, \mathrm{CH}_{2}+0.5 \times \mathrm{CH}_{2} \mathrm{CO}\right), 2.18\left(\mathrm{~m}, 2 \mathrm{H}, \mathrm{CH}_{2}\right), 2.57(\mathrm{t}$, $\left.1 \mathrm{H}, 0.5 \times \mathrm{CH}_{2} \mathrm{CO}\right), 2.80\left(\mathrm{~m}, 6 \mathrm{H}, 3 \times \mathrm{CH}_{2}\right), 3.42-3.65(\mathrm{~m}, 4 \mathrm{H}$, $\left.\mathrm{CH}_{2} \mathrm{CH}_{2} \mathrm{OBu}-t\right), 4.28\left(\mathrm{q}, 2 \mathrm{H}, \mathrm{OCH}_{2} \mathrm{Me}\right), 4.65\left(\mathrm{~s}, 2 \mathrm{H}, \mathrm{OCH}_{2} \mathrm{CO}\right), 5.02$, $5.13\left(\mathrm{~s}, 2 \mathrm{H}, \mathrm{CH}_{2} \mathrm{Ar}\right), 5.37(\mathrm{~m}, 8 \mathrm{H}, 4 \times \mathrm{CH}=\mathrm{CH}), 6.75-6.95(\mathrm{~m}, 2 \mathrm{H}$, aromatic), and $8.22\left(\mathrm{~d}, 1 \mathrm{H}, \mathrm{H}\right.$ ortho to $\left.\mathrm{NO}_{2}\right)$.

$\mathrm{N}$-(2-tert-butoxyethyl)-N-(5-carboxymethoxy-2-nitrobenzyl)arachidonoyl amide (4a). Under $\mathrm{N}_{2}$, compound $3 \mathrm{a}(1.0 \mathrm{mmol})$ was dissolved in $\mathrm{MeOH}$ $(3 \mathrm{ml})$ and cooled in an ice-water bath for $5 \mathrm{~min}$. A solution of $1 \mathrm{~N} \mathrm{NaOH}$ $(2.0 \mathrm{ml} ; 2 \mathrm{mmol})$ was added dropwise to the stirred methanolic solution over $3 \mathrm{~min}$. Stirring was continued in a room temperature water bath for $1 \mathrm{~h}$, whereupon the solution became clear and the hydrolysis was complete (as verified by TLC on silica gel plates). The reaction mixture was chilled in an ice-water bath, neutralized with $1 \mathrm{~N} \mathrm{HCl}(2.1 \mathrm{ml} ; 2.1 \mathrm{mmol})$, and extracted with EtOAc $(10 \mathrm{ml}$; two times $)$ and ether $(10 \mathrm{ml}$; two times). The organic extracts were pooled, washed with brine $(20 \mathrm{ml}$; two times), and dried over anhydrous $\mathrm{MgSO}_{4}$. Removal of solvent under vacuum yielded a pale yellow oil $[0.520 \mathrm{~g}(84.9 \%)] .{ }^{1} \mathrm{H}$ NMR $(300 \mathrm{MHz})$ $\delta$ was as follows: $0.88\left(\mathrm{t}, 3 \mathrm{H}\right.$, aliphatic $\left.\mathrm{CH}_{3}\right), 1.15\left(\mathrm{~s}, 9 \mathrm{H}, \mathrm{C}\left(\mathrm{CH}_{2}\right)_{3}\right), 1.29$ $\left(\mathrm{m}, 6 \mathrm{H}, 3 \times \mathrm{CH}_{2}\right), 1.72\left(\mathrm{~m}, 2 \mathrm{H}, \mathrm{CH}_{2}\right), 2.00-2.30\left(\mathrm{~m}, 5 \mathrm{H}, 2 \times \mathrm{CH}_{2}+\right.$ $\left.0.5 \times \mathrm{CH}_{2} \mathrm{CO}\right), 2.63\left(\mathrm{t}, 1 \mathrm{H}, 0.5 \times \mathrm{CH}_{2} \mathrm{CO}\right), 2.80\left(\mathrm{~m}, 6 \mathrm{H}, 3 \times \mathrm{CH}_{2}\right)$, $3.40-3.65$ (m, $\left.4 \mathrm{H}, \mathrm{CH}_{2} \mathrm{CH}_{2} \mathrm{OBu}-\mathrm{t}\right), 4.67$ (s, $2 \mathrm{H}, \mathrm{OCH}_{2} \mathrm{CO}$ ), 5.04, 5.18 (s, $\left.2 \mathrm{H}, \mathrm{CH}_{2} \mathrm{Ar}\right), 5.40(\mathrm{~m}, 8 \mathrm{H}, 4 \times \mathrm{CH}=\mathrm{CH}), 6.75-6.95(\mathrm{~m}, 2 \mathrm{H}$, aromatic), 7.80 (br s, $1 \mathrm{H}, \mathrm{COOH})$, and $8.24\left(\mathrm{~d}, 1 \mathrm{H}\right.$, ortho to $\left.\mathrm{NO}_{2}\right)$. HRMS $(\mathrm{FAB})$ was as follows: $m / z$ calculated for $\mathrm{C}_{35} \mathrm{H}_{52} \mathrm{~N}_{2} \mathrm{O}_{7}, 613.3853\left(\mathrm{M}+\mathrm{H}^{+}\right)$, found 613.3854 .

N-(2-tert-butoxyethyl)-N-[5-(mPEG-aminocarbonylmethoxy)-2-nitrobenzyl]-arachidonoylamide (5). A solution of $\mathrm{mPEG}-\mathrm{NH}_{2}$ [molecular weight (MW), 5000 Da; Nektar Therapeutics, San Carlos, CA] (2.5 g; 5 mmol) in dry $\mathrm{CH}_{2} \mathrm{Cl}_{2}(10 \mathrm{ml})$ was dried with anhydrous $\mathrm{MgSO}_{4}$ for $24 \mathrm{~h}$. After removal of $\mathrm{MgSO}_{4}$ by filtration, the solution was concentrated to one-half volume and diluted with dry $\mathrm{CH}_{2} \mathrm{Cl}_{2}$ to $10.0 \mathrm{ml}$ in a volumetric flask. A stirred mixture of acid 4 (0.307 g; $0.5 \mathrm{mmol})$ and HOBt (1-hydroxybenzotriazole) $(66 \mathrm{mg} ; 0.49 \mathrm{mmol})$ in dry $\mathrm{CH}_{2} \mathrm{Cl}_{2}(10 \mathrm{ml})$ was chilled in an icewater bath. Then, DCC (1,3-dicyclohexylcarbodiimide) (107 mg; 0.52 $\mathrm{mmol}$ ) was added in one portion. After $30 \mathrm{~min}$, a $5 \mathrm{ml}$ aliquot of the solution of mPEG-NH $\mathrm{NH}_{2}(1.25 \mathrm{~g} ; 0.25 \mathrm{mmol})$ in dry $\mathrm{CH}_{2} \mathrm{Cl}_{2}(5 \mathrm{ml})$ was added by syringe. Stirring was maintained at room temperature for $24 \mathrm{~h}$. To remove precipitates, the reaction mixture was filtered through a $2 \mathrm{~cm}$ bed of Celite, which was then washed with $5 \mathrm{ml}$ of $\mathrm{CH}_{2} \mathrm{Cl}_{2}$. The combined filtrate was diluted with anhydrous ethyl ether to yield a pale yellow powder $(1.14 \mathrm{~g})$. The powder was redissolved in dry $\mathrm{CH}_{2} \mathrm{Cl}_{2}(3 \mathrm{ml})$, and the solution was added to anhydrous ethyl ether $(120 \mathrm{ml})$ to precipitate the polymer conjugate a second time. The precipitate was recrystallized from $\mathrm{CH}_{2} \mathrm{Cl}_{2}$-diethyl ether to yield the polymer conjugate $5(0.53 \mathrm{~g} ; 42.5 \%)$.

$\mathrm{N}$-[5-(mPEG-aminocarbonylmethoxy)-2-nitrobenzyl] arachidonoylamide, caged AEA (6). A solution of compound 5 (0.47 g) in dry $\mathrm{CH}_{2} \mathrm{Cl}_{2}(5 \mathrm{ml})$ was chilled in an ice-water bath; trifluoroacetic acid $(5 \mathrm{ml})$ was then added in one portion. The mixture was stirred at room temperature for $24 \mathrm{~h}$. The residue remaining after solvent removal under reduced pressure was dissolved in $\mathrm{CH}_{2} \mathrm{Cl}_{2}(2 \mathrm{ml})$, and the polymer conjugate was precipitated by adding anhydrous diethyl ether $(100 \mathrm{ml})$. Recrystallization of the precipitate from $\mathrm{CH}_{2} \mathrm{Cl}_{2}$-diethyl ether yielded the caged AEA 6 as a yellow powder $[0.37 \mathrm{~g}(79.4 \%)]$.

(5-Ethoxycarbonylmethoxy-2-nitrobenzyl)-(2-hydroxyethyl)amine (2b). Compound 1 (0.506 g; $2.0 \mathrm{mmol}$ ), 2-aminoethanol (0.147 g; $2.4 \mathrm{mmol}$ ), and sodium acetate $(0.164 \mathrm{~g} ; 2.0 \mathrm{mmol})$ were added to 1,2 -dichloroethane $(10 \mathrm{ml})$; the mixture was magnetically stirred for $1 \mathrm{~h}$ under dry $\mathrm{N}_{2}$. Then $\mathrm{NaBH}\left(\mathrm{CH}_{3} \mathrm{CO}_{2}\right)_{3}(1.06 \mathrm{~g} ; 5 \mathrm{mmol})$ was added in one portion, and stirring was continued at room temperature overnight $(\sim 18 \mathrm{~h})$. The mixture was diluted with $\mathrm{CH}_{2} \mathrm{Cl}_{2}(20 \mathrm{ml})$, and the reaction was quenched with $10 \mathrm{ml}$ of saturated $\mathrm{NaHCO}_{3}$ solution. The organic phase was separated, washed with saturated $\mathrm{NaHCO}_{3}(10 \mathrm{ml}$; two times) and brine (15 $\mathrm{ml}$ ), and dried over anhydrous $\mathrm{MgSO}_{4}$. After purification by flash chromatography on silica gel (hexane/ethyl acetate, $80: 20 \rightarrow 1: 1: 1 \% \mathrm{Et}_{3} \mathrm{~N}$ ), amine $2 \mathrm{~b}$ was obtained as a pale yellow solid [0.22 g (36.8\%); m.p. $68-$ $69^{\circ} \mathrm{C}$. ${ }^{1} \mathrm{H}$ NMR $\left(500 \mathrm{MHz} ; \mathrm{CDCl}_{3}\right) \delta$ was as follows: $1.31\left(\mathrm{t}, 3 \mathrm{H}, \mathrm{CH}_{3}\right)$, 2.08-2.24 (br s, $2 \mathrm{H}, \mathrm{NH}+\mathrm{OH}), 2.82\left(\mathrm{t}, 2 \mathrm{H}, \mathrm{CH}_{2} \mathrm{OH}\right), 3.69(\mathrm{t}, 2 \mathrm{H}$, $\left.\mathrm{NCH}_{2} \mathrm{CH}_{2} \mathrm{O}\right), 4.11\left(\mathrm{~s}, 2 \mathrm{H}, \mathrm{CH}_{2} \mathrm{Ar}\right), 4.28\left(\mathrm{q}, 2 \mathrm{H}, \mathrm{OCH}_{2} \mathrm{CH}_{3}\right), 4.72(\mathrm{~s}, 2 \mathrm{H}$, 
$\left.\mathrm{OCH}_{2} \mathrm{CO}\right), 6.85(\mathrm{~d}, 1 \mathrm{H}, J=8.8 \mathrm{~Hz}$, aromatic $\mathrm{H}-4), 7.17(\mathrm{~s}, 1 \mathrm{H}$, aromatic $\mathrm{H}-6)$, and $8.08\left(\mathrm{~d}, 1 \mathrm{H}, J=8.9 \mathrm{~Hz}, \mathrm{H}\right.$ ortho to $\mathrm{NO}_{2}$ ).

$\mathrm{N}$-(2-hydroxyethyl)-N-(5-ethoxycarbonylmethoxy-2-nitrobenzyl)arachidonoylamide ( $3 b)$. To a solution of arachidonic acid ( $0.23 \mathrm{~g} ; 0.74$ $\mathrm{mmol})$ and oxalyl chloride $(0.14 \mathrm{~g} ; 0.10 \mathrm{ml} ; 1.1 \mathrm{mmol})$ in anhydrous $\mathrm{CH}_{2} \mathrm{Cl}_{2}(5 \mathrm{ml})$, a drop of dry DMF was added. The reaction mixture was treated precisely as described in the procedure for compound $3 \mathrm{a}$. The product arachidonoyl chloride was dissolved in dry $\mathrm{CH}_{2} \mathrm{Cl}_{2}$ to make 5.0 $\mathrm{ml}$ of solution in a volumetric flask.

To a solution of amine $2 \mathrm{~b}(0.22 \mathrm{~g} ; 0.74 \mathrm{mmol})$ and $\mathrm{Et}_{3} \mathrm{~N}(0.22 \mathrm{~g} ; 0.31$ $\mathrm{ml} ; 2.2 \mathrm{mmol})$ in dry $\mathrm{CH}_{2} \mathrm{Cl}_{2}(5 \mathrm{ml})$ under dry $\mathrm{N}_{2}, 5 \mathrm{ml}(0.74 \mathrm{mmol})$ of the solution of arachidonoyl chloride in $\mathrm{CH}_{2} \mathrm{Cl}_{2}$ was added dropwise by syringe. The reaction mixture was stirred at room temperature for $2 \mathrm{~h}$, during which time amine $2 \mathrm{~b}$ was completely converted to amide, as verified by TLC on silica gel plates (hexane/ethyl acetate, 7:3). The reaction mixture was diluted with $\mathrm{CH}_{2} \mathrm{Cl}_{2}(20 \mathrm{ml})$ and treated with saturated $\mathrm{NaHCO}_{3}$ solution $(5 \mathrm{ml})$. The organic phase was separated, washed with saturated $\mathrm{NaHCO}_{3}(5 \mathrm{ml})$ and brine $(10 \mathrm{ml})$, and dried over anhydrous $\mathrm{MgSO}_{4}$. After purification by flash chromatography on silica gel (hexane/ ethyl acetate, $95: 5 \rightarrow 80: 20$ ), amide $3 \mathrm{~b}$ was obtained as a yellow viscous oil [0.12 g (27.7\%)]. ${ }^{1} \mathrm{H}$ NMR (300 MHz) $\delta$ was as follows: $0.88(\mathrm{t}, 3 \mathrm{H}$, aliphatic $\left.\mathrm{CH}_{3}\right), 1.22-1.42\left(\mathrm{~m}, 9 \mathrm{H}, 3 \times \mathrm{CH}_{2}+\mathrm{COOCH}_{2} \mathrm{CH}_{3}\right), 1.72(\mathrm{~m}$, $\left.2 \mathrm{H}, \mathrm{CH}_{2}\right), 2.05\left(\mathrm{~m}, 3 \mathrm{H}, \mathrm{CH}_{2}+0.5 \times \mathrm{CH}_{2} \mathrm{CO}\right), 2.20\left(\mathrm{~m}, 2 \mathrm{H}, \mathrm{CH}_{2}\right), 2.56$ (t, $\left.1 \mathrm{H}, 0.5 \times \mathrm{CH}_{2} \mathrm{CO}\right), 2.65-2.90\left(\mathrm{~m}, 6 \mathrm{H}, 3 \times \mathrm{CH}_{2}\right), 3.08(\mathrm{br} \mathrm{s}, 1 \mathrm{H}, \mathrm{OH})$, $3.50-3.86\left(\mathrm{~m}, 4 \mathrm{H}, \mathrm{NCH}_{2} \mathrm{CH}_{2}\right), 4.27\left(\mathrm{q}, 2 \mathrm{H}, \mathrm{OCH}_{2} \mathrm{Me}\right), 4.72(\mathrm{~s}, 2 \mathrm{H}$, $\left.\mathrm{OCH}_{2} \mathrm{CO}\right), 5.00,5.04\left(\mathrm{~s}, 2 \mathrm{H}, \mathrm{CH}_{2} \mathrm{Ar}\right), 5.37(\mathrm{~m}, 8 \mathrm{H}, 4 \times \mathrm{CH}=\mathrm{CH})$, $6.80-6.98\left(\mathrm{~m}, 2 \mathrm{H}\right.$, aromatic), and $8.26\left(\mathrm{~d}, 1 \mathrm{H}\right.$, ortho to $\left.\mathrm{NO}_{2}\right)$. HRMS (FAB) was as follows: $m / z$ calculated for $\mathrm{C}_{33} \mathrm{H}_{48} \mathrm{~N}_{2} \mathrm{O}_{7}, 585.3540(\mathrm{M}+$ $\left.\mathrm{H}^{+}\right)$, found $585.3554\left(\mathrm{M}+\mathrm{H}^{+}\right)$.

$\mathrm{N}$-(2-hydroxyethyl)-N-(5-carboxymethoxy-2-nitrobenzyl)-arachidonoyl amide ( $4 b)$. Under $\mathrm{N}_{2}$, compound $3 \mathrm{~b}$ ( $18 \mathrm{mg} ; 0.03 \mathrm{mmol}$ ) was dissolved in $50 \mu \mathrm{l}$ of $\mathrm{MeOH}$, and the solution was chilled in an ice-water bath. $\mathrm{NaOH}$ solution $(1 \mathrm{~N} ; 45 \mu \mathrm{l} ; 0.045 \mathrm{mmol})$ was added, and the reaction mixture was maintained with periodic agitation at room temperature for $1 \mathrm{~h}$. The mixture became homogeneous and TLC on silica gel plates (hexane/ethyl acetate, 7:3) confirmed completion of hydrolysis. The solution was chilled in an ice-water bath, neutralized with $1 \mathrm{~N} \mathrm{HCl}(60 \mu \mathrm{l}$; $0.06 \mathrm{mmol}$ ), and extracted with $\mathrm{CH}_{2} \mathrm{Cl}_{2}$ (5 ml; two times). The combined organic extract was washed with brine ( $5 \mathrm{ml}$; two times), dried over anhydrous $\mathrm{MgSO}_{4}$, and evaporated under reduced pressure to yield free acid $4 \mathrm{~b}$ as a yellow oil [14.1 $\mathrm{mg}(84 \%)]$.

Quantum yield of photolysis. A pulsed Nd:YAG laser (QuantaRay GCR18S; Spectra Physics, Mountain View, CA), at $1 \mathrm{~Hz}$ repetition rate, was used as the photolysis light source. A pair of harmonic separators (BSR355-1025; CVI Laser, Albuquerque, NM) was used to isolate the third harmonic emission $(355 \mathrm{~nm})$ from the fundamental $(1064 \mathrm{~nm})$ and second harmonic $(532 \mathrm{~nm})$ emissions. A standard chemical actinometer (potassium ferrioxalate) (Hatchard and Parker, 1956) was used to confirm the stability of the laser output ( $1.4 \%$ drift over $2.5 \mathrm{~h}$ ) and to verify that energy output was linearly related to the number of laser pulses ( $>99.8 \%$ linearity from 1 to 60 pulses). A solution of compound $3 \mathrm{~b}$ in acetonitrile was prepared to have an absorbance $>2.5$ at $355 \mathrm{~nm}$. In all experiments, we ensured that $<20 \%$ of the caged compound was consumed by photolysis. This was confirmed by HPLC analysis using 4-nitrophenol as an internal standard: equal amounts of 4-nitrophenol were added to the photolyzed and unphotolyzed samples of compound $3 \mathrm{~b}$, and the extent of consumption of compound $3 \mathrm{~b}$ was determined by numerical integration of corresponding peaks in the HPLC (de Mayo and Shizuka, 1976). Photolysis experiments were performed in triplicate; HPLC analysis for each replicate experiment was repeated three times.

Kinetics of flash photolysis. The kinetics of flash photolysis was studied on a kinetic spectrophotometer (LP920; Edinburgh Instruments, Livingston, UK). A solution of compound $4 \mathrm{~b}$ was prepared in a 1:1 mixture of $0.1 \mathrm{~m}$ sodium phosphate buffer, $\mathrm{pH}$ 7.41, and methanol to have an absorbance $>2.0$ (in a $1 \mathrm{~cm}$ cuvette) at $355 \mathrm{~nm}$, the wavelength of the photolytic light. The air-equilibrated solution was stirred magnetically at room temperature. Photolysis of the sample was effected by a $8.6 \mathrm{~ns}$ [full width at half-maximum (FWHM)], $100 \mathrm{~mJ}$ pulse of $355 \mathrm{~nm}$ third harmonic light from a Nd-YAG laser (Quanta-Ray GCR-18S). A pair of harmonic separators (BSR-355-1025; CVI Laser) was used to remove residual fundamental $(1064 \mathrm{~nm})$ and second harmonic $(532 \mathrm{~nm})$ laser emissions from the photolysis beam. A probe beam from a stabilized xenon arc lamp was focused so that the focal point coincided with the region of maximal photolysis in the sample. After passing through the sample, the probe beam was dispersed through a monochromator. Modulation of the probe beam intensity by the transient photochemical intermediate species was monitored at $430 \mathrm{~nm}$ by a fast photomultiplier tube. The intensity-versus-time data were converted to an absorbanceversus-time trace. Nonlinear least-squares analysis allowed exponential decay times to be extracted from the data. Data in the initial $45 \mathrm{~ns}$ window contain artifactual contributions from scattering of the laser pulse and instabilities in the high-sensitivity detection circuitry, and are not included in data analysis.

\section{Photolysis of caged glutamate and caged AEA}

Photolysis of caged glutamate (Ncm-Glu) and caged AEA was accomplished using previously published methods (Wei et al., 2001; Cai et al., 2004). The multiline UV emission of an argon ion laser (wavelength, 333-364 nm; BeamLok 2065-7S; Spectra Physics) was launched into a $100 \mu \mathrm{m}$ diameter fused silica optical fiber (OZ Optics, Westbrook, Ontario, Canada). The exit end of the fiber was projected onto a conjugate of the field diaphragm plane along the epifluorescence path of the microscope. After establishing whole-cell recording, the laser spot $(\sim 15-20$ $\mu \mathrm{m}$ diameter) was centered on the soma of the patched cell. The laser output was gated by a shutter (NM Laser Products, Sunnyvale, CA) to generate photolytic flashes (100 ms duration). In our experimental setup, there is an instrumentation delay of $1.4 \mathrm{~ms}$ from triggering the UV laser flash to a laser signal measured by the PMT.

\section{Data analysis}

All data are presented as mean \pm SEM. Student's paired and unpaired $t$ test or repeated-measures ANOVAs were used as needed. To estimate the time constant of the exponential change in sIPSP or sIPSC frequency, we averaged the response frequency between 2 and $3 \mathrm{~s}$ after stimulus onset and defined this average to be the minimal frequency value. All frequency values were then normalized between the minimum frequency and the control IPSP/C frequency, which correspond to 0 and $100 \%$, respectively, on the graphs. Nonlinear least-squares curve fitting of flash photolysis kinetic data were performed through Origin software (OriginLab).

\section{Results}

\section{Synthesis and characterization of caged AEA}

Caged AEA was synthesized as outlined in Figure $1 A$. Details of the synthetic procedures are described in Materials and Methods. We prepared two versions of caged AEA: one in which a PEG [poly(ethyleneglycol)] moiety is covalently attached to the cage to confer high aqueous solubility on the caged AEA (Fig. $1 A$, compound 6), and for comparison, one in which the cage bears a single carboxyl group (Fig. $1 A$, compound 4 b). In the caged molecules, the cage is covalently attached to the amide nitrogen atom in AEA, because structure-activity studies have shown that covalent modification of the amide nitrogen abolishes both cannabinoid activity and susceptibility to lipase cleavage (Sheskin et al., 1997; Lang et al., 1999).

The photochemical process through which AEA is generated from caged AEA is shown in Figure $1 B$. The UV-visible absorption spectrum of compound 6 , presented as extinction coefficient $(\epsilon)$ versus wavelength, is shown in Figure $2 \mathrm{~A}$ (solid curve). As expected for a caged molecule, the spectrum changed markedly when the sample was photolyzed by UV light (Fig. $2 A$, dashed curve). The spectroscopic properties of compound $4 \mathrm{~b}$ were similar to those of compound 6 except that peak absorption occurred at a slightly longer wavelength (314 vs $303 \mathrm{~nm}$ for compound 6); the prephotolysis and postphotolysis spectra of compound $4 \mathrm{~b}$ are supplied as supplemental Figure 1 (available at www.jneurosci.org as supplemental material). Photolysis of caged compound 

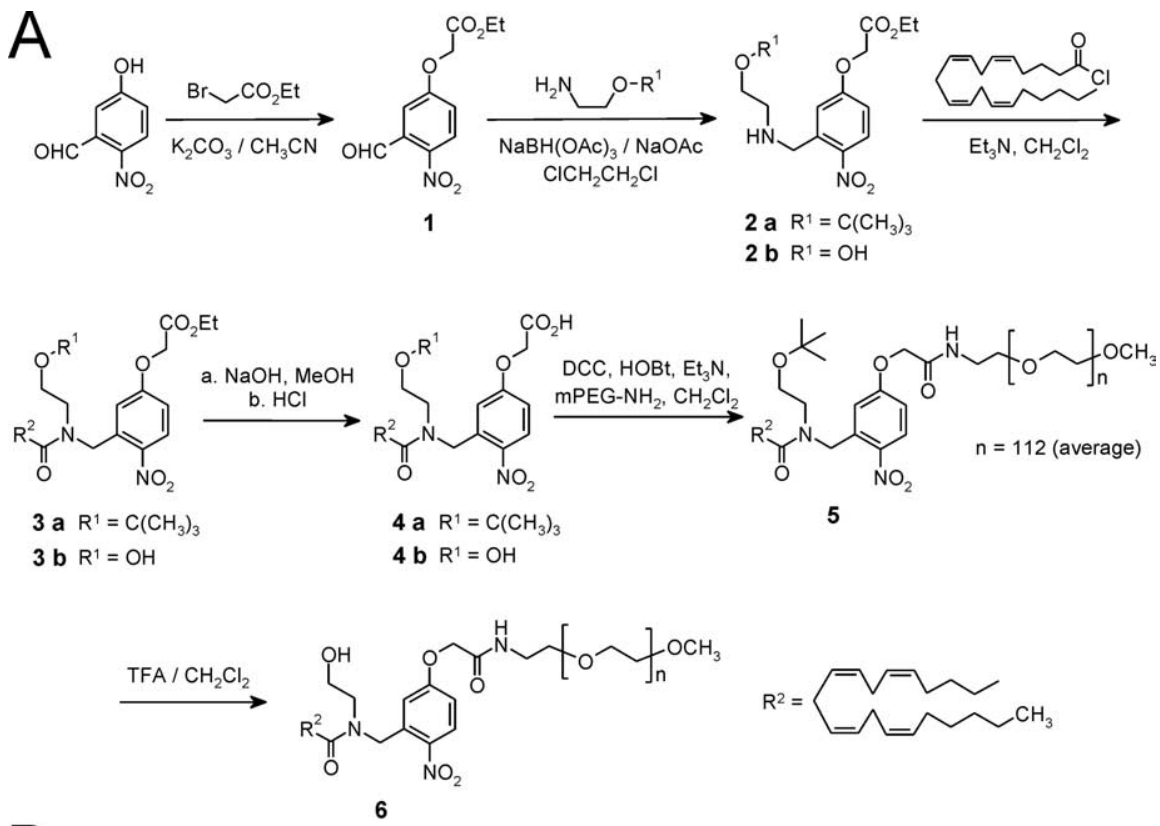

B

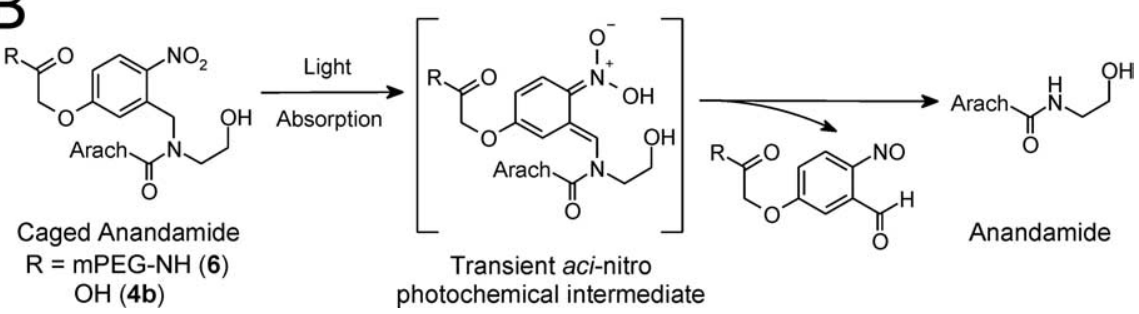

Figure 1. Synthesis and photochemical release mechanism of caged AEA. A, Synthesis and structures of the caged AEA molecules, $\mathrm{N}$-CmNb-arachidonoylethanolamide (4b) and $\mathrm{N}$-(mPEG-CmNb)-arachidonoylethanolamide (6). $\boldsymbol{B}$, Photorelease of AEA from caged AEA. Light absorption by caged AEA generates the short-lived aci-nitro intermediate, which decomposes into the spent cage and free AEA.

released bona fide AEA, as verified by HPLC analysis of the photolysate, with authentic, never-caged AEA acting as reference standard (data not shown). The quantum efficiency for photorelease of AEA ( $Q$ ) on photolysis was determined to be $0.062 \pm 0.003(n=3)$.

For examining the kinetics of photolysis, we used transient absorption spectroscopy to monitor the short-lived, photolytically generated aci-nitro intermediate (Fig. $1 B$, species in brackets) (Yip et al., 1985; Schupp et al., 1987; Zhu et al., 1987; Yip et al., 1991), which has a decay that is commonly taken to be concomitant with cleavage of the caging group and release of product (Walker et al., 1988; McCray and Trentham, 1989). The kinetic spectroscopy trace for laser flash photolysis of compound 6 in $0.1 \mathrm{M}$ sodium phosphate buffer, $\mathrm{pH}$ 7.4, is shown in Figure 2 B. Photolysis by a single $8.6 \mathrm{~ns}$ pulse of $355 \mathrm{~nm}$ light gave rise to a transient absorption that decayed with single-exponential time course, showing exponential time constant $\tau=27.2 \pm 0.7 \mu$ s (equivalent to a half-life of $\left.t_{1 / 2}=18.9 \pm 0.5 \mu \mathrm{s}\right)$. Thus, photorelease of AEA from compound 6 is expected to be complete in $<100 \mu$ s after flash photolysis. In comparison, photolysis of compound $4 \mathrm{~b}$, which does not bear the $5000 \mathrm{MW}$ poly(ethyleneglycol) moiety, was even more rapid, proceeding with exponential time constant $\tau=0.106 \pm$ $0.001 \mu \mathrm{s}$. The kinetic spectroscopy trace for compound $4 \mathrm{~b}$ is supplied as supplemental Figure 2 (available at www.jneurosci.org as supplemental material).
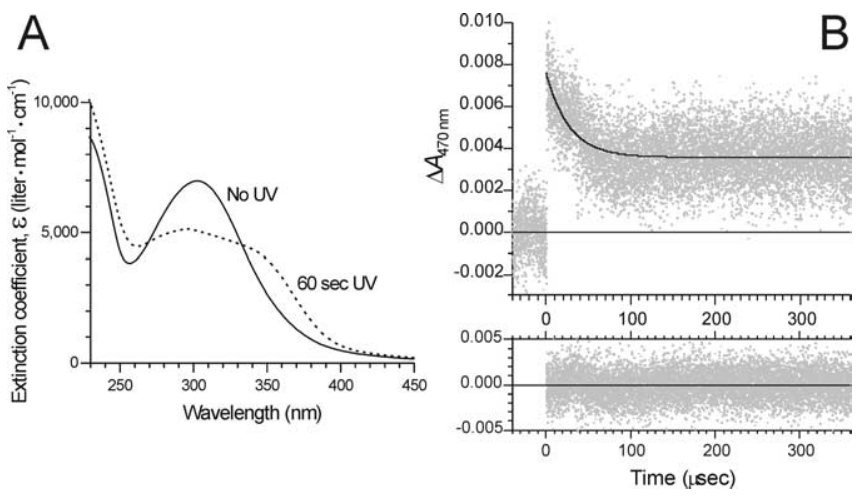

Figure 2. Photolysis of caged AEA monitored by UV-visible absorption spectroscopy. $\boldsymbol{A}$, The UV-visible absorption spectra, shown as solid and dashed lines, respectively, were acquired before and after photolysis of caged AEA 6 for $60 \mathrm{~s}$ with $75 \mathrm{~mW}$ of the UV emission from an argon ion laser. Solvent was $0.1 \mathrm{~m}$ sodium phosphate buffer, $\mathrm{pH}$ 7.4. Extinction coefficient $(\epsilon)$ values are reported to facilitate read-out of $\epsilon$ at any wavelength. $\boldsymbol{B}$, Photolysis kinetics measured by transient absorbance spectral change after laser flash photolysis of caged AEA6. The absorbance at $470 \mathrm{~nm}$ of a solution of caged AEA in $0.1 \mathrm{~m}$ sodium phosphate, $\mathrm{pH} 7.4$, was monitored. At time 0 , a pulse of $355 \mathrm{~nm}$ light ( $8.6 \mathrm{~ns}$ FWHM; $\sim 30 \mathrm{~mJ}$ ) was delivered to the sample. In the top panel, gray points are experimental data (average of 16 replicate measurements), and the solid black curve is the nonlinear least-squares single-exponential fit to the data. The exponential time constant of the fitted decay curve is $\tau=27.2 \pm 0.7 \mu \mathrm{s}$. The residuals of the fit are shown in the bottom panel.

\section{Dynamics of DSI in adult acute slices}

We began by analyzing the DSI dynamics in the CA1 region of acute adult hippocampal slices using from one to five theta burst trains of action potentials recorded under current-clamp conditions to initiate DSI. Each theta burst consisted of 5 positive DC pulses delivered at $50 \mathrm{~Hz}$ (i.e., five action potentials occurred within $100 \mathrm{~ms}$ ). When more than one theta burst was used, they were triggered at $5 \mathrm{~Hz}$. We induced sIPSPs or sIPSCs by bathapplying $5 \mu \mathrm{M}$ carbachol (Pitler and Alger, 1992; Martin and Alger, 1999), because these events occur continuously at a higher frequency, and therefore provide better temporal resolution, than evoked synaptic responses.

Figure $3, A$ and $B$, shows the effect of one (top panels) or three (bottom panels) theta bursts on sIPSP frequency. The transient suppression of sIPSPs is DSI. To examine the onset of DSI in more detail, we reduced the sIPSP bin sizes from $1 \mathrm{~s}$ to $200 \mathrm{~ms}$ and reanalyzed the data from 0 to $3 \mathrm{~s}$ after the action potential train. Figure $3 C$ shows that, after a single theta burst train, there was no effect on sIPSPs for the first bin after the train (i.e., $\sim 300 \mathrm{~ms}$ after the start of the train), but thereafter the frequency decreased nearly to zero over the next $1-2 \mathrm{~s}$ with a time course that was well fit by a single exponential having a time constant of $\tau=416 \mathrm{~ms}$. Extrapolating the exponential to the control level (100\% baseline IPSP frequency) gave a value of $343 \mathrm{~ms}$, which we took as the 
minimal onset time for DSI $\left(t_{\mathrm{DSI}}\right)$ after a single train. When data obtained after one to five theta burst trains were analyzed in the same way as in Figure $3 C$, and the data were grouped across cells $(n=10)$, a very similar exponential decay function fit the combined data ( $\tau=345 \mathrm{~ms}$ ) (Fig. $3 D$ ) as for one train $(\tau=416 \mathrm{~ms})$. Likewise, $t_{\mathrm{DSI}}$ determined from multiple- or single-train experiments was the same (351 vs $343 \mathrm{~ms}$, respectively). We conclude that a single process is set into motion by one train, and its dynamic properties are not altered by additional stimulation. In addition, there is a minimal latency between the start of action potential stimulation and the onset of eCB effects; thereafter, the effects grow larger with an exponential time constant of $\sim 400 \mathrm{~ms}$.

Brown et al. (2003) proposed that the enhancement in DSI produced by an increasing amount of synaptic stimulation reflects augmentation in the amount of $\mathrm{eCB}$ released. Alternatively, the rate of $\mathrm{eCB}$ termination could have been altered. However, we found that the recovery time constant, $\sim 5 \mathrm{~s}$, did not increase with increasing stimulation (one, three, or five trains) (Fig. 3E-G), supporting the conclusion that increased $\mathrm{eCB}$ release accounts for the prolongation of DSI in our experiments.

\section{Components of the $\mathrm{Ca}^{2+}$-induced eCB signal process}

The analysis in Figure 3 distinguishes two kinetic parameters of DSI: time-to-onset $\left(t_{\mathrm{DSI}}\right)$ and the exponential time constant of DSI development. The quantity $t_{\mathrm{DSI}}$ must include the time from the start of the postsynaptic pyramidal cell depolarization and $\mathrm{Ca}^{2+}$ influx through to activation of the presynaptic CB1 on the interneurons. The pyramidal cell steps include time for $\left[\mathrm{Ca}^{2+}\right]_{\mathrm{i}}$ to rise sufficiently to initiate eCB synthesis (" $t_{\mathrm{Ca}}$ "), and the time for eCB synthesis, release, and transit to $\mathrm{CB} 1$ $\left(t_{\mathrm{eCB}}\right)$. The presynaptic interneuron steps comprise time for activation of CB1 and downstream steps $\left(t_{\mathrm{CB} 1}\right)$. These parameters can be related as follows:

$$
t_{\mathrm{DSI}}=t_{\mathrm{Ca}}+t_{\mathrm{eCB}}+t_{\mathrm{CB} 1} .
$$

We want to determine $t_{\mathrm{eCB}}$, which cannot be measured directly. We can, however, estimate $t_{\mathrm{eCB}}$ from Equation 1 if the other values are known. To measure $t_{\mathrm{Ca}}$ and $t_{\mathrm{CB} 1}$, we applied optical methods to organotypic slices (Gähwiler et al., 1998), which are thinner and thus more suitable for optical approaches than are acute slices. DSI occurs in organotypic slices (Martin and Alger, 1999); however, the cultured slice chamber is not heated, and these experiments were done at room tem-
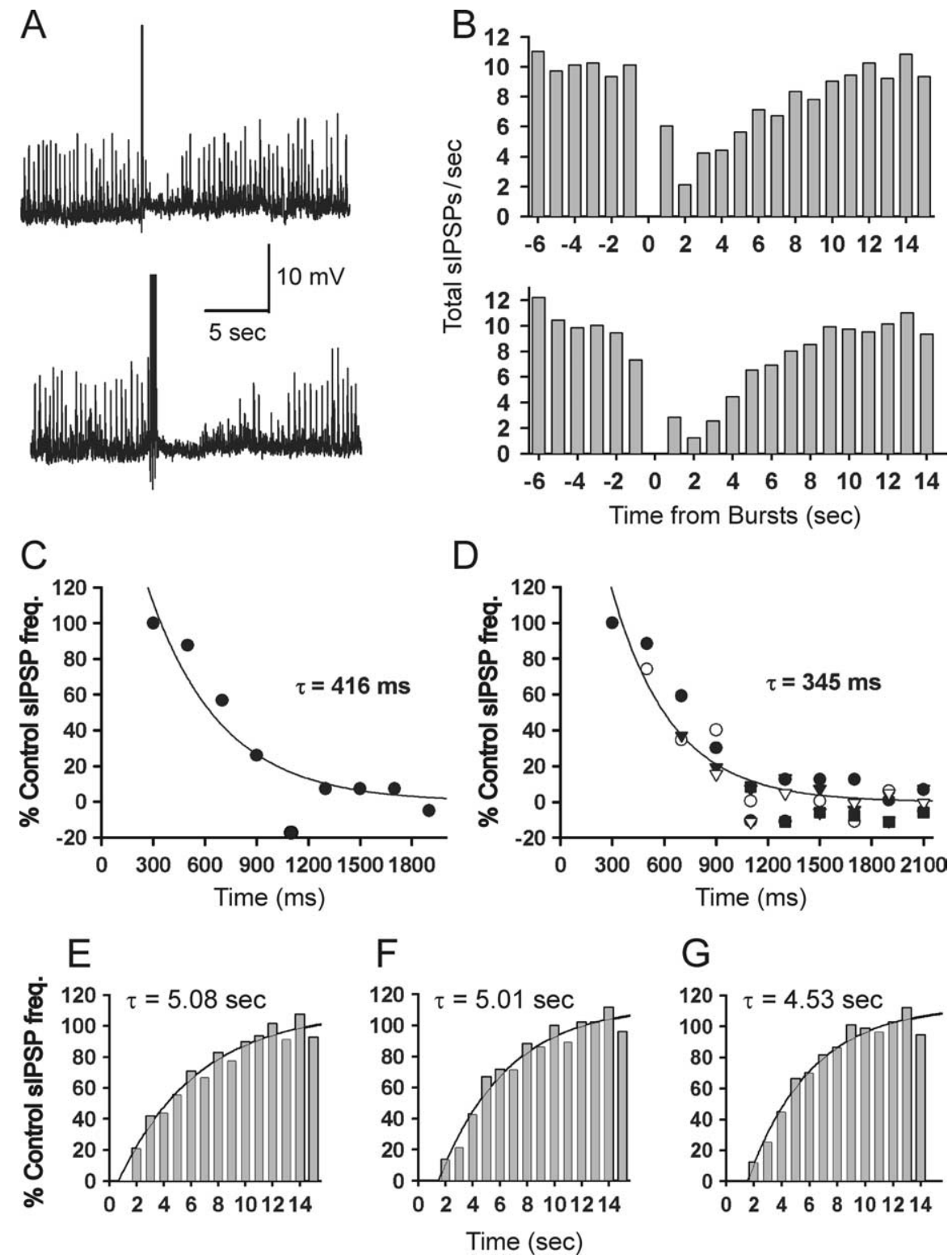

Figure 3. Dynamics of DSI in adult acute slices. $A$, DSI of sIPSPs induced by theta burst patterns of action potentials. Raw traces from a CA1 pyramidal cell recorded with a sharp microelectrode filled with $3 \mathrm{~m} \mathrm{KCl} \mathrm{(see} \mathrm{Materials} \mathrm{and} \mathrm{Methods);} \mathrm{sIPSPs} \mathrm{appear} \mathrm{as}$ upward deflections of 2-10 mV. In the top trace, a single theta burst train ( 5 action potentials, each induced by 5 -ms-long DC pulse injected through the recording electrode) occurred at the point of the large upward deflection; in the bottom trace, three theta burst trains (200 ms interburst intervals) were used. The temporary reduction in sIPSPs occurring after each theta train is DSI. $\boldsymbol{B}$, Analysis of several trials of sIPSPs as in corresponding rows of $\boldsymbol{A}$ (top panel, 1 theta burst; bottom panel, 3 theta bursts). Shown are total sIPSPs over all trials binned in $1 \mathrm{~s}$ intervals as described in Materials and Methods. The onset of theta burst trains occurred at time 0. C, Onset of sIPSP suppression. Shown are total sIPSPs occurring immediately after a single theta train which occurred at time 0 , rebinned in $200 \mathrm{~ms}$ bins (same experiment shown in top part of $\boldsymbol{B}$ ). In the first bin (ending at $300 \mathrm{~ms}$ ), there was no suppression of sIPSPS, and thereafter, the development of DSI is well fit by a single exponential with a time constant of $416 \mathrm{~ms}$. Note in this and other similar figures that the $y$-axis represents the percentage of the control SIPSP/C frequency (see Materials and Methods); hence negative values do not imply negative frequencies. $\boldsymbol{D}$, Combined data from experiments ( $n=10$ cells) in which from one to five theta trains were given (each symbol represents data obtained after a different number of trains). The best-fitting exponential through the combined data are similar to the fit in $\boldsymbol{C . E}-\boldsymbol{G}$, Recovery from DSI has a similar time course after either one $(\boldsymbol{E})$, three $(\boldsymbol{F})$, or five $(\boldsymbol{G})$ theta trains.

perature, $\sim 22^{\circ} \mathrm{C}$, rather than $30^{\circ} \mathrm{C}$. Because eCB signaling is temperature dependent (Kreitzer et al., 2002), we first repeated the experiments shown in Figure 3, in acute slices at $22^{\circ} \mathrm{C}$ ( $n=5$ slices) (data not shown). As expected, at the lower temperature, DSI was slowed: $t_{\mathrm{DSI}}$ at $22^{\circ} \mathrm{C}$ was $409 \mathrm{~ms}$ (vs 351 $\mathrm{ms}$ at $30^{\circ} \mathrm{C}$ ), and a single exponential with a time constant of 
A
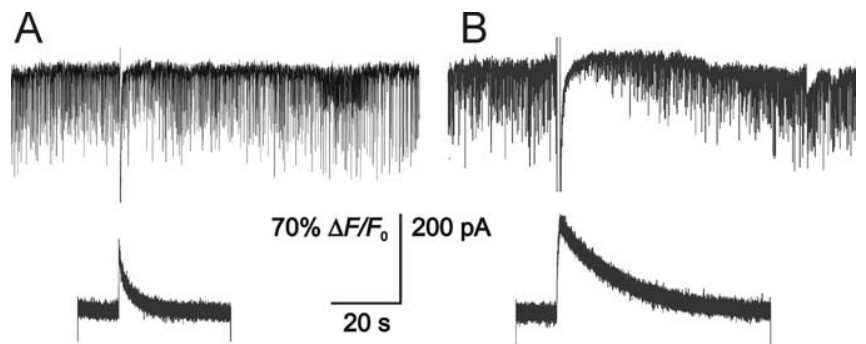

C
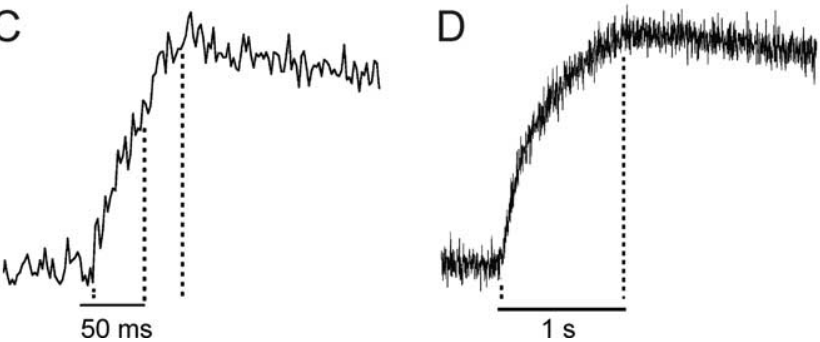

Figure 4. Calcium dependence of DSI. A, A $50 \mathrm{~ms}$ voltage step resulted in minimal DSI in a pyramidal cell. In this neuron, the sIPSC frequency before the voltage step was $6.65 \mathrm{~Hz}$ (averaged over 32 s before the step) and $5.55 \mathrm{~Hz}$ after the step (averaged over 20 s after the step). This represents a $16.6 \%$ reduction in sIPSC frequency. The accompanying $\mathrm{Ca}^{2+}$ transient (fluo-3 signal) was measured with a PMT and is shown immediately below and, on a faster time scale, in $\boldsymbol{C}$. The peak of the transient occurred after the end of the voltage step. $\boldsymbol{B}, \mathrm{A} 1 \mathrm{~s}$ voltage step evoked pronounced DSI. The frequency before the step was $6.43 \mathrm{~Hz}$ and was reduced to $1.75 \mathrm{~Hz}$ after the step (averaged over 20 s after the step) (i.e., a $72.8 \%$ reduction in sIPSC frequency). The $\mathrm{Ca}^{2+}$ signal for the $1 \mathrm{~s}$ step was substantially larger than in $\boldsymbol{A}$ and peaked at the end of the voltage step (D). $\mathrm{Ca}^{2+}$ transients in $\mathbf{C}$ and $\boldsymbol{D}$ were normalized to facilitate visual comparison. The dotted lines in $C$ mark the terminations of the $50 \mathrm{~ms}$ voltage step and peak of the $\mathrm{Ca}^{2+}$ transient (determined from the trace after a smoothing procedure). In $\boldsymbol{D}$, the dotted line shows that the peak of the $\mathrm{Ca}^{2+}$ transient occurred at the end of the $1 \mathrm{~s}$ voltage step.

$714 \mathrm{~ms}$ fit the group data for the rise-to-peak DSI (vs $345 \mathrm{~ms}$ at $30^{\circ} \mathrm{C}$ ). Using these data in combination with the van't Hoff equation, $\ln \left(\tau_{\mathrm{T} 1} / \tau_{\mathrm{T} 2}\right)=\left(-E_{\mathrm{a}} / R\right)\left[T_{2}{ }^{-1}-T_{1}{ }^{-1}\right]$, where $R=$ $1.987 \mathrm{cal} \cdot \mathrm{mol}^{-1} \cdot \mathrm{K}^{-1}$ is the gas constant and $\tau_{\mathrm{T} 1}$ and $\tau_{\mathrm{T} 2}$ are time constants determined at temperatures $T_{1}$ and $T_{2}$ (in kelvins), we can estimate an activation energy, $E_{\mathrm{a}}=16.2$ $\mathrm{kcal} \cdot \mathrm{mol}^{-1}$, or, equivalently, a $\mathrm{Q}_{10}\left(=\mathrm{Rate}_{37^{\circ} \mathrm{C}} /\right.$ Rate $\left._{27^{\circ} \mathrm{C}}\right)$ of 2.4, for the growth-to-peak DSI. All subsequent experiments were done in organotypic cultured slices at room temperature.

\section{Estimating $\boldsymbol{t}_{\mathrm{Ca}}$}

To estimate $t_{\mathrm{Ca}}$, we detected changes in $\left[\mathrm{Ca}^{2+}\right]_{\mathrm{i}}$ by including the fluorescent $\mathrm{Ca}^{2+}$ indicator, fluo-3, in the recording pipette and using a PMT to capture the fluorescence signal. The PMT signal reflected the volume-averaged $\left[\mathrm{Ca}^{2+}\right]_{\mathrm{i}}$ rise within the recorded cell. We measured $\mathrm{Ca}^{2+}$ signals and DSI concomitantly to determine the minimal duration of the $\mathrm{Ca}^{2+}$ signal associated with detectable DSI (Fig. 4). A $50 \mathrm{~ms}$ step depolarization produced DSI in $\sim 33 \%$ of the cells $(n=6)$ and an associated peak $\left[\mathrm{Ca}^{2+}\right]_{\mathrm{i}}$ increase $\left(\Delta F / F_{0}\right)$ of $28 \pm 5.5 \%$. We took this as the threshold for DSI induction. In the same cells, 10 or $20 \mathrm{~ms}$ steps produced essentially no DSI, although a $20 \mathrm{~ms}$ step resulted in peak $\Delta F / F_{0}$ of $26 \pm 3.2 \%$. For voltage step durations $>100 \mathrm{~ms}$, the $\mathrm{Ca}^{2+}$ response peaked at the same time as, or shortly before, the end of the pulse. For voltage step durations $\leq 100 \mathrm{~ms}$, the peak of the $\mathrm{Ca}^{2+}$ response occurred slightly after the end of the steps, probably reflecting $\mathrm{Ca}^{2+}$ release from intracellular stores (Nakamura et al., 2002) (M. Isokawa and B. E. Alger, unpublished observations), although imperfect voltage control or slow closure of the $\mathrm{Ca}^{2+}$ channels might also contribute. Mean times-to-peak of the
$\mathrm{Ca}^{2+}$ signals were $35.5 \pm 6.4$ and $60.0 \pm 4.0 \mathrm{~ms}$ for the 20 and 50 ms voltage steps, respectively. Because peak $\Delta F / F_{0}$ in these cases did not differ significantly $(p>0.05)$, it appears that detectable eCB production requires $>35 \mathrm{~ms}$, with $60 \mathrm{~ms}$ being sufficient in approximately one-third of the cells. We suggest that $\sim 60 \mathrm{~ms}$ is a reasonable estimate of $t_{\mathrm{Ca}}$.

We also observed that, with $1 \mathrm{~s}$ voltage steps, the rise in the PMT signal was linear for the first $171.4 \pm 18.3 \mathrm{~ms}(n=6)$ (data not shown) after the onset of a voltage step, in accord with predictions based on the $\left[\mathrm{Ca}^{2+}\right]_{\mathrm{i}}$ measurements made by Brenowitz and Regehr (2003). This permits an independent estimate of $t_{\mathrm{Ca}}$ to be made (see Discussion).

\section{Measuring $t_{\mathrm{CB} 1}$ with “caged" AEA}

To assess the contribution of CB1 activation and downstream steps to $t_{\mathrm{DSI}}$, we developed a novel caged form of AEA (Fig. 1) that is biologically inert and highly hydrophilic and thus can be bathapplied without affecting the hippocampal slices, but that releases bona fide AEA in situ when illuminated by a focally delivered flash of UV light. Caged AEA by itself has no effect on cell membrane properties (data not shown) or synaptic responses (see below).

The UV flash alone had no effect on CCh-induced sIPSCs (Fig. 5C). The sIPSC frequencies before and after the flash were $2.29 \pm 0.47$ and $2.32 \pm 0.38 \mathrm{~Hz}$, respectively $(n=8 ; p>0.8)$. Caged AEA by itself did not affect sIPSCs. The sIPSC frequencies before and after wash-in of caged AEA were $2.29 \pm 0.47$ and $2.21 \pm 0.36 \mathrm{~Hz}$, respectively $(n=8 ; p>0.6)$. However, in the presence of caged AEA $(200 \mu \mathrm{M})$, the UV flash transiently reduced sIPSC frequency $(n=8)$ (Fig. $5 D)$. We then tested the effect of the CB1 antagonist, AM251 (3 $\mu \mathrm{M})$ (Fig. 5, compare E, $F)$. Although AM251 slightly reduced the sIPSC frequency $(1.27 \pm 0.06 \mathrm{~Hz} ; n=9$; vs $1.67 \pm 0.03 \mathrm{~Hz}$ in control), it fully blocked the ability of photoreleased AEA to suppress sIPSC frequency. These results show that the effect of photoreleased AEA is mediated by $\mathrm{CB} 1$ activation.

AEA photorelease did not instantaneously suppress sIPSCs. The combined data from 17 cells were reasonably well fit by an exponential that decayed with a time constant of $551 \mathrm{~ms}$ (Fig. 6). By extrapolating the exponential back to $100 \%$ (the control frequency), we infer that detectable activation of $\mathrm{CB} 1$ responses requires $162 \mathrm{~ms}$.

The data in Figures 3-6, in combination with Equation 1 with $t_{\mathrm{DSI}}$ taken as $409 \mathrm{~ms}$, allow an estimate of $187 \mathrm{~ms}$ for $t_{\mathrm{eCB}}$, the time required for $\mathrm{eCB}$ synthesis, release, and access to the presynaptic cannabinoid receptors at $22^{\circ} \mathrm{C}$. The data in Figure 6 also suggest that the time-to-peak DSI is governed mainly by the dynamics of the G-protein-coupled CB1 receptor, because the time constants of the single exponentials that characterize the increase in DSI are all essentially identical with the time constant of IPSC suppression caused by photolytically released AEA.

\section{Dynamics of mGluR-induced eCB release in cultured hippocampal slices}

Activation of mGluRs suppresses IPSCs through a mechanism that resembles DSI (Morishita et al., 1998; Morishita and Alger, 1999). It appears that group I mGluR activation stimulates release of eCBs from hippocampal pyramidal cells (Varma et al., 2001) and cerebellar Purkinje cells (Maejima et al., 2001), because this effect is blocked by CB1 antagonists and is absent in slices from CB1 ${ }^{-1-}$ mice (Varma et al., 2001). The mGluR effect differs from DSI in that it cannot be prevented by very high intracellular concentrations of the $\mathrm{Ca}^{2+}$ chelator, BAPTA (Maejima et al., 2001; 
Kim et al., 2002). These and other differences between DSI and GPCR-induced eCB release (Kim et al., 2002) suggest that the dynamics of GPCR-dependent and $\mathrm{Ca}^{2+}$-dependent eCB release might not be the same. We explored this issue using caged glutamate.

The caged glutamate, $\mathrm{Ncm}-\mathrm{Glu}(0.5$ or $1 \mathrm{~mm})$, was bathapplied and allowed to equilibrate in a slice. Photolytic uncaging of $\mathrm{Ncm}$-Glu to release glutamate is intrinsically fast and occurs on the microsecond time scale $\left(t_{1 / 2}<4.5 \mu \mathrm{s}\right)$ (S. Muralidharan and J. P. Y. Kao, unpublished observations). In slice preparations, glutamate photorelease occurs more slowly than in a cuvette, because UV flashes of much lower power must be used. In slices, photoreleased glutamate evokes AMPA receptor-mediated responses in pyramidal cells (supplemental Fig. 3, available at www.jneurosci.org as supplemental material) with a time-toonset of $\leq 4 \mathrm{~ms}(n=13)$, which encompasses the time required for glutamate photorelease, binding, and activation of AMPA receptors. Therefore, times-to-onset significantly longer than 4 ms must reflect the kinetics of downstream signaling steps. In subsequent experiments, glutamate photorelease was done in the presence of ionotropic glutamate receptor blockers.

In control experiments, we found that the magnitude of DSI of evoked IPSCs and the suppression of IPSCs by photolysis of caged glutamate were not significantly different (Fig. 7 A, B). Simultaneous fluorescence measurements show that, whereas DSI is associated with a sharp rise in $\left[\mathrm{Ca}^{2+}\right]_{\mathrm{i}}($ Fig. $7 C)$, the photorelease of glutamate is not (Fig. 7D). Group data on IPSC suppression and $\mathrm{Ca}^{2+}$ transients are summarized in Figure $7, E$ and $F$, respectively $(n=6)$. The mGluR antagonist, LY341495, which blocks all mGluRs at a concentration of $100 \mu \mathrm{M}$ (Fitzjohn et al., 1998), prevented the suppression of eIPSCs by photoreleased glutamate without significantly affecting DSI (Fig. $7 G, H$ ) or the $\mathrm{Ca}^{2+}$ transient associated with DSI (Fig. 7I,J). Group data on the effect of LY341495 on IPSC suppression and $\mathrm{Ca}^{2+}$ transients are summarized in Figure $7, K$ and $L$, respectively $(n=4)$. These results confirm that the suppression of IPSCs after photolysis of caged glutamate was attributable to the activation of metabotropic glutamate receptors. In $\mathrm{CB} 1^{-/-}$mice, DSI is absent, and mGluR agonists do not suppress eIPSCs (Varma et al., 2001). As expected, photolytic activation of mGluRs did not suppress eIPSCs in $\mathrm{CB}^{-l-}$ mice $(n=3$ slices from three mice) (data not shown).

Dynamics of mGluR-dependent eCB suppression of sIPSCs in cultured hippocampal slices

We then determined the dynamic components of mGluRinduced eCB response on sIPSC frequency in pyramidal cells (Fig. 8A). The mean onset latency, duration, and magnitude of the IPSC suppression caused by uncaged glutamate (Fig. $8 B$ ) were similar to that caused by uncaged AEA (Fig. 6A). The grouped data for suppression of IPSCs by photolytically activated mGluR was fit by an exponential that decayed with a time constant of $486 \mathrm{~ms}$ (Fig. $8 \mathrm{C}$ ). There was no reduction in sIPSCs for $236 \mathrm{~ms}$ (determined by extrapolation of the exponential fit to the control sIPSC level). If the time-to-onset of IPSC suppression caused by the mGluR-induced eCB process ( $\left.t_{\text {mGluRsI }}\right)$ is described by the following:

$$
t_{\mathrm{mGluRSI}}=236 m s=t_{\mathrm{eCB}(\mathrm{mGluR})}+t_{\mathrm{CB} 1}
$$

where $t_{\mathrm{eCB} \text { (mGluR) }}$ is the time for activation of the mGluRdependent eCB synthesis and release, and $t_{\mathrm{CB} 1}$ is $162 \mathrm{~ms}$ (Fig. 6), then $t_{\mathrm{eCB}(\mathrm{mGluR})}$ would be $74 \mathrm{~ms}$.
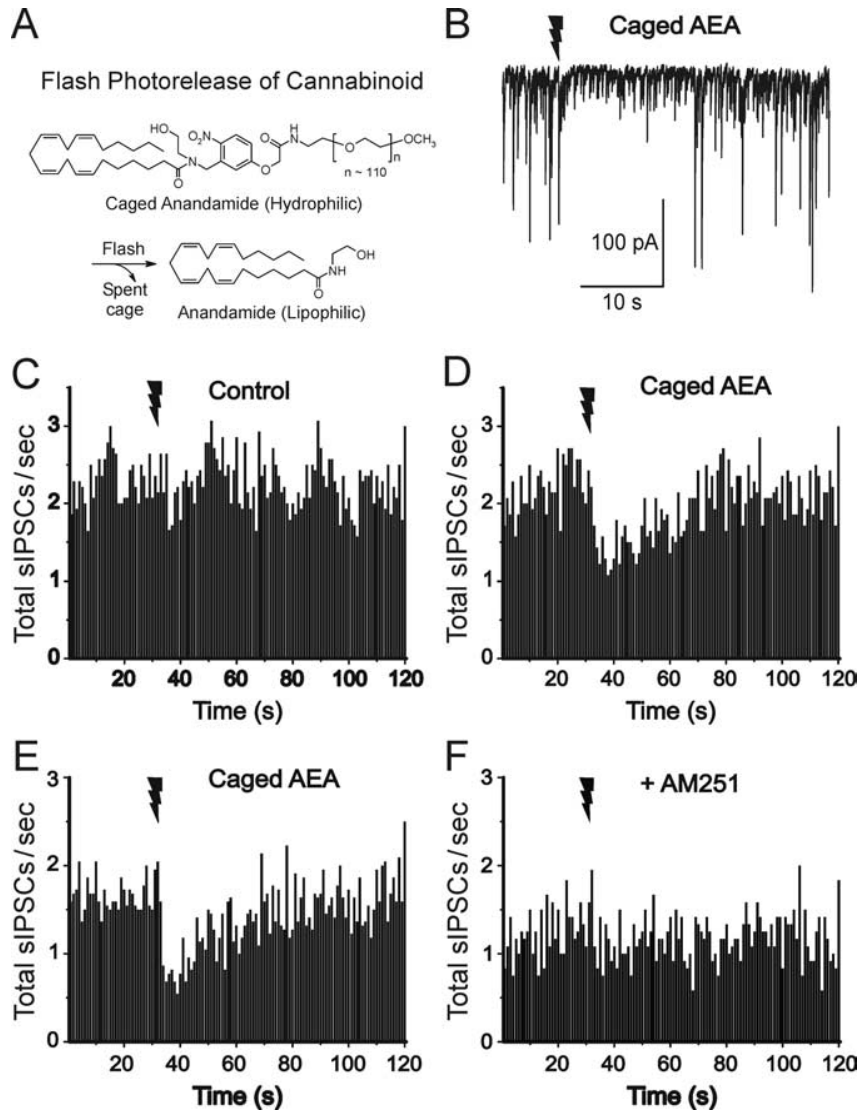

Figure 5. Dynamics of IIPSC suppression by photorelease of AEA in cultured hippocampal slices. $A$, Schematic structure of functionally caged AEA. B, Photorelease of caged AEA, present at $200 \mu \mathrm{m}$, by a $100 \mathrm{~ms}$ UV laser flash (given at jagged arrow) transiently suppresses sIPSCs (downward deflections) recorded under whole-cell voltage clamp from a pyramidal cell. Ionotropic glutamate receptors were blocked by AP-5 and NBQX. sIPSC binning was done as in Figure 1. C, A UV laser flash alone in the absence of caged AEA did not affect SIPSCS. D, After wash-in of caged AEA (same cells as in C), a laser flash was followed by transient sIPSC suppression. $\boldsymbol{E}, \boldsymbol{F}$, The CB1 antagonist AM251 (3 $\mu \mathrm{M})$ prevents photoreleased AEA from affecting sIPSCS. The same cells in $\boldsymbol{E}$ and $\boldsymbol{F}$ are shown. All data in this and subsequent figures were obtained at room temperature $\left(\sim 22^{\circ} \mathrm{C}\right)$.
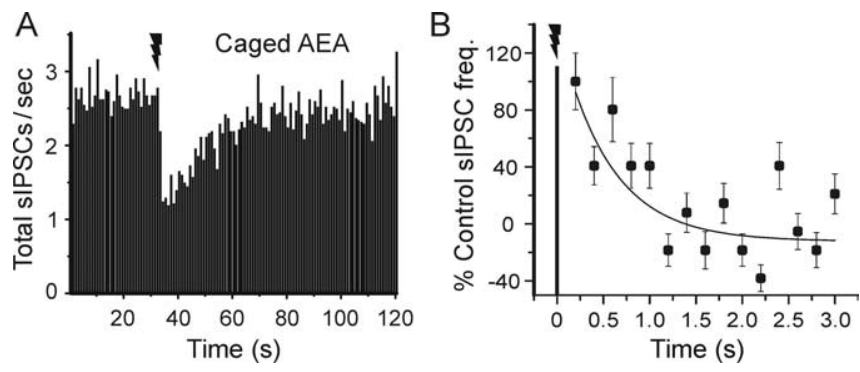

Figure 6. Time course of suppression of inhibition induced by AEA photorelease. $A$, Grouped data from all cells tested with caged AEA $(n=17)$ showing suppression of sIPSCs. Each time point is the average from 17 cells; error bars were omitted for clarity (the SEs for the individual time points varied from 11.2 to $19.8 \%$ of the means). $\boldsymbol{B}$, Dynamics of AEA-induced suppression of sIPSCs during the initial 3 s after the UV laser flash (data from $A$, rebinned in 200 ms intervals). No change in sIPSC occurrence is evident at the first time bin after the flash (ending at $200 \mathrm{~ms}$ ), but thereafter the data are fit by an exponential function that has a time constant of $551 \mathrm{~ms}$. Error bars indicate SE.

\section{Discussion}

This is the first detailed attempt to determine the minimal time required for activation of an intercellular neuronal lipid messenger system. We conclude that eCBs, and by extension similar lipid 

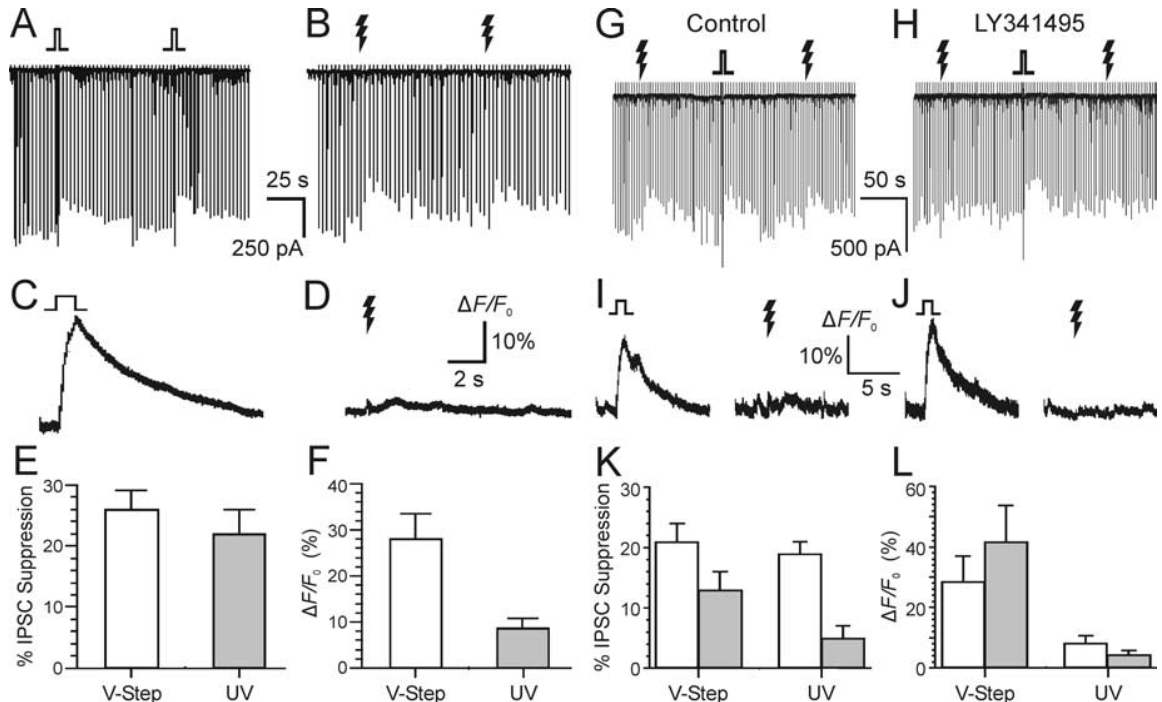

Figure 7. Photoreleased glutamate activates mGluR and induces eCB-dependent responses in cultured hippocampal cells. Each downward deflection represents an evoked GABA synaptic response. Caged glutamate, $\mathrm{Ncm}-\mathrm{Glu}$ (500 $\mu \mathrm{m}$ ), was in the bath. $\boldsymbol{A}$, Transient suppression of eIPSCs evoked by $1 \mathrm{~s}$ voltage steps to $0 \mathrm{mV}$ on two DSI trials. $\boldsymbol{B}$, Two trials from the same cell in which 100 ms UV laser flashes were given. $\boldsymbol{C}, \boldsymbol{D}$, Simultaneous $\mathrm{Ca}^{2+}$ indicator fluorescence measurements for single DSI or glutamate photorelease trials. $\boldsymbol{E}, \boldsymbol{F}$, Grouped data showing IPSC suppression and $\mathrm{Ca}^{2+}$ transient magnitude from cells treated as in $\boldsymbol{A}$ and $\boldsymbol{B}$. All data in $\boldsymbol{A}-\boldsymbol{F}$ were obtained from the same six cells. $\boldsymbol{G}$, Both DSI and glutamate photorelease reduce evoked IPSCs. $\boldsymbol{H}$, Addition of the mGluR antagonist LY341495 (100 $\mu \mathrm{m})$ to the bath prevented the photolytic glutamate responses without significantly affecting DSI. $\boldsymbol{I}, \boldsymbol{J}$, Corresponding $\mathrm{Ca}^{2+}$ signals produced by voltage steps and photoreleased glutamate before $(\boldsymbol{I})$ and after $(\boldsymbol{J})$ perfusion of LY341495. $\boldsymbol{K}, \boldsymbol{L}$, Grouped data $(n=4)$ for control (open bars) and LY341495 (gray bars) conditions; different cells than $\boldsymbol{A}-\boldsymbol{F}$. Error bars indicate $\mathrm{SE}$. Jagged arrows represent laser flashes.
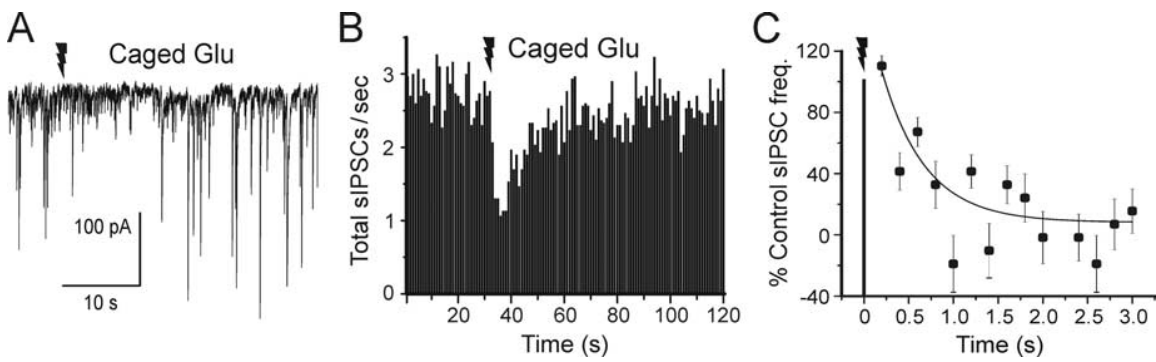

Figure 8. Dynamics of mGluR-dependent eCB suppression of sIPSCs in cultured hippocampal slices. $\boldsymbol{A}$, Recording from a pyramidal cell illustrates the reduction of sIPSC frequency after flash photorelease of caged glutamate. $\boldsymbol{B}$, Time course of sIPSC suppression by photoreleased glutamate; sIPSC frequency binned and analyzed as in Figures 3 and $6(n=12)$. Each time point is the average from 12 cells; error bars were omitted for clarity (the SEs for the individual time points varied from 7.9 to $15.8 \%$ of the means). $\boldsymbol{C}$, sIPSCs rebinned during the initial 3 s after the UV laser flash in the same set of cells as in $\boldsymbol{B}$. No change in sIPSC occurrence is evident at the first time bin after the flash (ending at $200 \mathrm{~ms}$ ), but thereafter the data are fit by an exponential function that has a time constant of $486 \mathrm{~ms}$. Error bars indicate SE. Jagged arrows represent laser flashes.

messengers, can be mobilized and evoke responses as quickly as conventional metabotropic, GPCR-coupled neurotransmitters can. Hence, lipids are not relegated to homeostatic processes, or slowly activating forms of regulation, but rather can affect neuronal excitability in moment-to-moment information processing. The data are also important for a complete understanding of the biochemical mechanisms of lipid signal mobilization, in particular endocannabinoid synthesis and action, because of the temporal constraints that they place on these mechanisms.

A great deal of evidence shows that an eCB, probably 2-AG or $\mathrm{AEA}$, is released as a retrograde signal and mediates the phenomenon called DSI (Ohno-Shosaku et al., 2001; Wilson and Nicoll, 2001) and other effects (for review, see Alger, 2002). DSI represents a powerful bioassay for the rapid action of eCBs. Previous studies of DSI (Pitler and Alger, 1994; Wilson et al., 2001; Hamp-

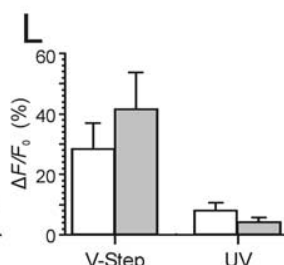

son et al., 2003; Fortin et al., 2004) suggested that the time-to-onset of eCB responses ranged between 1 and $6 \mathrm{~s}$. Our experiments suggest that the delay $\left(t_{\mathrm{DSI}}\right)$ is shorter, $\sim 400 \mathrm{~ms}$, and presumably experimental factors account for the differences. $\left[\mathrm{Ca}^{2+}\right]_{\mathrm{i}}$ measurements and photorelease of caged AEA permitted us to distinguish the components of the total signal delay that are attributable to eCB synthesis and release from those that involve cannabinoid receptor activation and downstream steps.

Our major parameter was the time from the start of the stimulus used to initiate eCB signaling (either the voltage step used to open voltage-gated calcium channels or the UV flash) to the onset of the eCB-dependent sIPSC suppression. Synthesis and release of $\mathrm{eCB}$ must occur at least as quickly as this, and may be faster if additional intermediate steps are significantly time-consuming. We reasoned that one such step might be the rise in $\left[\mathrm{Ca}^{2+}\right]_{i}$ required to initiate $\mathrm{eCB}$ synthesis and release. The suggestion that a minimal duration of stimulation is required for DSI induction has previous empirical support. For example, a 50-ms-long voltage step from $-70-0 \mathrm{mV}$ produces just-detectable DSI in cells in acute slices recorded with whole-cell pipettes containing $0.1 \mathrm{~mm}$ BAPTA (Lenz and Alger, 1999). We found that to induce just-detectable DSI, $\mathrm{Ca}^{2+}$ signals must be elevated for 35-60 ms, which we designated $t_{\mathrm{Ca}}$. We infer that $t_{\mathrm{Ca}}$ represents the time necessary to initiate the eCB synthesis and release process. Detection of cellular $\left[\mathrm{Ca}^{2+}\right]_{\mathrm{i}}$ changes with a PMT necessarily involves "volume averaging," and it is possible that the magnitude or kinetics of local $\left[\mathrm{Ca}^{2+}\right]_{\mathrm{i}}$ changes near the membrane where the eCBs are presumably produced, will differ from this global value.

Brenowitz and Regehr (2003) found that $\left[\mathrm{Ca}^{2+}\right]_{\mathrm{i}}$ increases linearly with voltage steps up to $1.5 \mathrm{~s}$ in duration, reaching a maximal concentration of $60 \mu \mathrm{M}\left[\mathrm{Ca}^{2+}\right]_{\mathrm{i}}$ at that point. Our PMT signals were linear for at least $100 \mathrm{~ms}$ after the start of the voltage step (data not shown). A linear increase in $\left[\mathrm{Ca}^{2+}\right]_{\mathrm{i}}$ for $100 \mathrm{~ms}$ would result in $\left[\mathrm{Ca}^{2+}\right]_{\mathrm{i}}$ of $\sim 4 \mu \mathrm{M}(60 \mu \mathrm{M} / 1.5 \mathrm{~s}=4 \mu \mathrm{M} / 0.1 \mathrm{~s})$. Wang and Zucker (2001) measured DSI as a function of $\left[\mathrm{Ca}^{2+}\right]_{i}$ and found that DSI would be $>50 \%$ maximal when $\left[\mathrm{Ca}^{2+}\right]_{\mathrm{i}}$ is 4 $\mu \mathrm{M}$, and that an increase in $\left[\mathrm{Ca}^{2+}\right]_{\mathrm{i}}$ of $2 \mu \mathrm{M}$ would produce detectable DSI. This concentration should be achieved within $\sim 50 \mathrm{~ms}$ after the beginning of our voltage steps, consistent with our present measurements. The concordance among these various results suggests that the time required for $\mathrm{Ca}^{2+}$-dependent steps in the postsynaptic cell contributes significantly ( $\sim 60 \mathrm{~ms})$ to the latency-to-onset of eCB effects.

Activation of CB1s and their downstream effectors $\left(t_{\mathrm{CB} 1}\right)$ accounted for much of the eCB response onset latency. Rapid pho- 
torelease of caged compounds was critical to refining the estimates for eCB synthesis and release. For example, Mackie and Hille (1992), using a rapid perfusion system that delivered WIN55212-2 to cultured NG108-15 cells within $1 \mathrm{~s}$, observed that the $\mathrm{N}$-type $\mathrm{Ca}^{2+}$ current was suppressed with a time constant of $\sim 8$ s. Photolytic release of AEA in cultured slices suppressed sIPSCs with a delay of $162 \mathrm{~ms}$ at $22^{\circ} \mathrm{C}$. The high affinity of AEA for CB1 (52 nM) (Devane et al., 1992) suggests that the time for AEA binding to $\mathrm{CB} 1$ is likely to be a negligible fraction of $t_{\mathrm{CB} 1}$. Equilibration of caged AEA within the slices before photolysis means that AEA photorelease will occur in situ in the immediate vicinity of $\mathrm{CB} 1$, so the time for diffusion of AEA to CB1 should be negligible. Supporting this conclusion, we found that uncaged glutamate evoked AMPA responses that began $\leq 4 \mathrm{~ms}$ after the UV flash. Hence the bulk of the time from the photolytic flash to sIPSC suppression by AEA reflects steps downstream from CB1 activation. CB1 is a heptahelical GPCR, and our measured response latency is compatible with that of other GPCR-mediated responses. For example, Mott et al. (1999) measured the kinetics of $\mathrm{GABA}_{\mathrm{B}}$-mediated currents in cells in brain slices and found a mean onset latency of $30 \mathrm{~ms}$, but their measurements were made at $32-34^{\circ} \mathrm{C}$. Canepari et al. (2001) show that photolytically releasing glutamate onto Purkinje cells (at $32^{\circ} \mathrm{C}$ ) produces a transient mGluR1-mediated inward current with an onset latency of $\sim 90$ ms. The difference between these values and ours is no doubt temperature dependent. Delmas et al. (2004) report that GPCRmediated suppression of $\mathrm{M}$-current in sympathetic ganglion cells begins after $250 \mathrm{~ms}$ at $20^{\circ} \mathrm{C}$.

Combining the values of $t_{\mathrm{Ca}}$ and $t_{\mathrm{CB} 1}$ allows us to estimate that the actual time required for $\mathrm{eCB}$ synthesis and release at $22^{\circ} \mathrm{C}$ is in the 75-190 ms range, depending on whether the initiating signal is a GPCR or $\mathrm{Ca}^{2+}$. Note that our bioassay was sensitive to sIPSC suppression of $\geq 15 \%$ (i.e., eCB concentrations too low to produce such a decrease would have been undetectable). If eCBs are released before our detection threshold is reached, then the upper and lower limits of our estimated time range for eCB synthesis and release would decrease. However, even if $190 \mathrm{~ms}$ are required for eCB mobilization, this would be much less than previously assumed for a lipid signal process. Finally, eCB effects are very temperature sensitive (Kreitzer and Regehr, 2001b), and hence at physiological temperatures, eCB synthesis and release will take place faster than our estimates at $22^{\circ} \mathrm{C}$. For example, if eCB mobilization should have a $\mathrm{Q}_{10}$ of 2.4 , as does the growth of DSI, then, at $37^{\circ} \mathrm{C}, \mathrm{eCB}$ synthesis and release would occur in the $20-50$ ms range.

For simplicity, we assumed that eCBs are produced in the postsynaptic pyramidal cell and travel to the presynaptic, CB1bearing interneurons. This model, although widely accepted, is still only indirectly supported; conceivably release of an unknown messenger from the pyramidal cell triggers the production of eCBs in the interneuron where they access CB1 directly. This possibility does not diminish the significance of our experiments, which focused on the dynamics of the eCB system. Indeed, if eCBs were generated in the interneurons, then, because of the time required for transmission of the unknown signal, eCB mobilization and action would be even more rapid than our data imply.

For technical reasons, AEA is more amenable to chemical caging than is 2-AG, and so we began with AEA. It is still not certain which eCB is actually the messenger for the eCB effects in hippocampus. Increasing evidence suggests that the GPCR actions are probably mediated by 2-AG (Stella et al., 1997; Kim and Alger, 2004; Hashimotodani et al., 2005). Nevertheless, conclusions re- garding functional eCB kinetics may not depend significantly on the difference. AEA has 2-25 times higher binding affinity $\left(K_{\mathrm{i}}\right)$ for CB1 (Mechoulam et al., 1995; Sugiura et al., 1995) depending on assay conditions but is only a partial agonist at CB1 (for review, see Hillard, 2000). However, 2-AG is present in tissue at concentrations from 170-1000 times higher than AEA (Stella et al., 1997; Sugiura and Waku, 2000) and is a full agonist at CB1. If 2-AG were to bind and activate CB1 more slowly than AEA, then correcting for this difference in $t_{\mathrm{CB} 1}$ would actually leave less time for 2-AG synthesis and release (see Eq. 1). Given the present uncertainties, it is unlikely that our conclusions would have been markedly altered had caged 2-AG been available.

Although the eCBs can facilitate (Carlson et al., 2002) or produce long-term changes in synaptic strength (Gerdeman et al., 2002; Robbe et al., 2002; Chevaleyre and Castillo, 2003; Ronesi et al., 2004), they also act on shorter time scales in producing DSI and depolarization-induced suppression of excitation (Alger, 2002). Indeed, eCB release, detected as DSI, is produced by short trains of action potentials (Fig. 3) (Pitler and Alger, 1992; Fortin et al., 2004) or synaptic responses (Brown et al., 2003), and this has suggested that rapid neuromodulation may be a major function of these lipids.

The present study demonstrates that the time courses of mGluR-dependent eCB responses and DSI are both fast. Evidently, despite the different biochemical cascades involved (Hashimotodani et al., 2005), both pathways can rapidly generate eCBs. Probably the molecular machineries for both processes reside near the plasma membrane where they can be readily activated.

\section{References}

Alger BE (2002) Retrograde signaling in the regulation of synaptic transmission: focus on endocannabinoids. Prog Neurobiol 68:247-286.

Bazan NG (2003) Synaptic lipid signaling: significance of polyunsaturated fatty acids and platelet-activating factor. J Lipid Res 44:2221-2233.

Brenowitz SD, Regehr WG (2003) Calcium dependence of retrograde inhibition by eCBs at synapses onto Purkinje cells. J Neurosci 23:6373-6384.

Brown SP, Brenowitz SD, Regehr WG (2003) Brief presynaptic bursts evoke synapse-specific retrograde inhibition mediated by endogenous cannabinoids. Nat Neurosci 6:1048-1057.

Cai X, Liang CW, Muralidharan S, Kao JP, Tang CM, Thompson SM (2004) Unique roles of SK and Kv4.2 potassium channels in dendritic integration. Neuron 44:351-364.

Canepari M, Papageorgiou G, Corrie JE, Watkins C, Ogden D (2001) The conductance underlying the parallel fibre slow EPSP in rat cerebellar Purkinje neurones studied with photolytic release of L-glutamate. J Physiol (Lond) 533:765-772.

Carlson G, Wang Y, Alger BE (2002) Endocannabinoids facilitate that induction of LTP in the hippocampus. Nat Neurosci 5:723-724.

Chevaleyre V, Castillo P (2003) Heterosynaptic LTD of hippocampal GABAergic synapses: a novel role of eCBs in regulating excitability. Neuron 38:461-472.

Delmas P, Crest M, Brown DA (2003) Functional organization of PLC signaling microdomains in neurons. Trends Neurosci 27:41-47.

De Mayo P, Shizuka H (1976) Measurements of reaction quantum yields In: Creation and detection of excited states, Vol 4 (Ware WR, ed), pp 139-215. New York: Marcel Dekker

Devane WA, Hanus L, Breuer A, Pertwee RG, Stevenson LA, Griffin G, Gibson D, Mandelbaum A, Etinger A, Mechoulam R (1992) Isolation and structure of a brain constituent that binds to the cannabinoid receptor. Science 258:1946-1949.

Fitzjohn SM, Bortolotto ZA, Palmer MJ, Doherty AJ, Ornstein PL, Schoepp DD, Kingston AE, Lodge D, Collingridge GL (1998) The potent mGlu receptor antagonist LY341495 identifies roles for both cloned and novel mGlu receptors in hippocampal synaptic plasticity. Neuropharmacol 37:1445-1458.

Fortin DA, Trettel J, Levine ES (2004) Brief trains of action potentials en- 
hance pyramidal neuron excitability via eCB-mediated suppression of inhibition. J Neurophysiol 92:2105-2112.

Freund TF, Katona I, Piomelli D (2003) Role of endogenous cannabinoids in synaptic signaling. Physiol Rev 83:1017-1066.

Gähwiler BH, Thompson SM, McKinney RA, Debanne D, Robertson RT (1998) Organotypic slice cultures of neural tissue. In: Culturing nerve cells, Ed 2 (Banker G, Goslin K, eds), pp 461-498. Cambridge, MA: MIT.

Gerdeman GL, Ronesi J, Lovinger DM (2002) Postsynaptic eCB release is critical to long-term depression in the striatum. Nat Neurosci 5:446-451.

Giuffrida A, Parsons LH, Kerr TM, Rodriguez de Fonseca F, Navarro M, Piomelli D (1999) Dopamine activation of endogenous cannabinoid signaling in dorsal striatum. Nat Neurosci 2:358-363.

Hampson RE, Zhuang S, Weiner JL, Deadwyler SA (2003) Functional significance of cannabinoid-mediated, depolarization-induced suppression of inhibition (DSI) in the hippocampus. J Neurophysiol 90:55-64.

Hashimotodani Y, Ohno-Shosaku T, Tsubokawa H, Ogata H, Emoto K, Maejima T, Araishi K, Shin HS, Kano M (2005) Phospholipase $\mathrm{C}_{\beta}$ serves as a coincidence detector through its $\mathrm{Ca}^{2+}$ dependency for triggering retrograde endocannabinoid signal. Neuron 45:257-268.

Hatchard CG, Parker CA (1956) A new sensitive chemical actinometer. II. Potassium ferrioxalate as a standard chemical actinometer. Proc R Soc Lond A 235:518-536.

Hillard CJ (2000) Biochemistry and pharmacology of the endocannabinoids arachidonylethanolamide and 2-arachidonylglycerol. Prostaglandins Other Lipid Mediat 61:3-18.

Iversen L (2003) Cannabis and the brain. Brain 126:1252-1270.

Kim J, Alger BE (2004) Inhibition of cyclooxygense-2 potentiates retrograde eCB signaling effects in hippocampus. Nat Neurosci 7:697-698.

Kim J, Isokawa M, Ledent C, Alger BE (2002) Activation of muscarinic acetylcholine receptors enhances the release of endogenous cannabinoids in the hippocampus. J Neurosci 22:10182-10191.

Kreitzer AC, Regehr WG (2001a) Retrograde inhibition of presynaptic calcium influx by endogenous cannabinoids at excitatory synapses onto Purkinje cells. Neuron 29:717-727.

Kreitzer AC, Regehr WG (2001b) Cerebellar depolarization-induced suppression of inhibition is mediated by endogenous cannabinoids. J Neurosci 21:RC174(1-5).

Kreitzer AC, Carter AG, Regehr WG (2002) Inhibition of interneuron firing extends the spread of eCB signaling in the cerebellum. Neuron 34:787-796.

Lang W, Qin C, Lin S, Khanolkar AD, Goutopoulos A, Fan P, Abouzid K, Meng Z, Biegel D, Makriyannis A (1999) Substrate specificity and stereoselectivity of rat brain microsomal anandamide amidohydrolase. J Med Chem 42:896-902.

Ledent C, Valverde O, Cossu G, Petitet F, Aubert JF, Beslot F, Bohme GA, Imperato A, Pedrazzini T, Roques BP, Vassart G, Fratta W, Parmentier M (1999) Unresponsiveness to cannabinoids and reduced addictive effects of opiates in CB1 receptor knockout mice. Science 283:401-404.

Lenz RA, Alger BE (1999) Calcium dependence of depolarization-induced suppression of inhibition in rat hippocampal CA1 pyramidal neurons. J Physiol (Lond) 521:147-157.

Mackie K, Hille B (1992) Cannabinoids inhibit N-type calcium channels in neuroblastoma-glioma cells. Proc Natl Acad Sci USA 89:3825-3829.

Maejima T, Hashimoto K, Yoshida T, Aiba A, Kano M (2001) Presynaptic inhibition caused by retrograde signal from metabotropic glutamate to cannabinoid receptors. Neuron 31:463-475.

Martin LA, Alger BE (1999) Muscarinic facilitation of the occurrence of depolarization-induced suppression of inhibition in rat hippocampus. Neuroscience 92:61-71.

McCray JA, Trentham DR (1989) Properties and uses of photoreactive caged compounds. Annu Rev Biophys Biophys Chem 18:239-270.

Mechoulam R, Ben-Shabat S, Hanus L, Ligumsky M, Kaminski NE, Schatz AR, Gopher A, Almog S, Martin BR, Compton DR, Pertwee RG, Griffin F, Bayewitch M, Barg J, Vogel Z (1995) Identification of an endogenous 2-monoglyceride, present in canine gut, that binds to cannabinoid receptors. Biochem Pharmacol 1:83-90.

Morishita W, Alger BE (1999) Evidence for endogenous excitatory amino acids as mediators in DSI of $\mathrm{GABA}_{\mathrm{A}}$ ergic transmission in hippocampal CA1. J Neurophysiol 82:2556-2564.
Morishita W, Kirov SA, Alger BE (1998) Evidence for metabotropic glutamate receptor activation in the induction of depolarization-induced suppression of inhibition in hippocampal CA1. J Neurosci 18:4870-4882.

Mott DD, Li Q, Okazaki MM, Turner DA, Lewis DV (1999) GABABreceptor-mediated currents in interneurons of the dentate-hilus border. J Neurophysiol 82:1438-1450.

Nakamura T, Lasser-Ross N, Nakamura K, Ross WN (2002) Spatial segregation and interaction of calcium signaling mechanisms in rat hippocampal CA1 pyramidal neurons. J Physiol (Lond) 543:465-480.

Nicoll RA, Alger BE (1981) A simple chamber for recording from submerged brain slices. J Neurosci Methods 4:153-156.

Ohno-Shosaku T, Maejima T, Kano M (2001) Endogenous cannabinoids mediate retrograde signals from depolarized postsynaptic neurons to presynaptic terminals. Neuron 29:729-738.

Ohno-Shosaku T, Matsui M, Fukudome Y, Shosaku J, Tsubokawa H, Taketo MM, Manabe T, Kano M (2003) Postsynaptic M1 and M3 receptors are responsible for the muscarinic enhancement of retrograde $\mathrm{eCB}$ signalling in the hippocampus. Eur J Neurosci 18:109-116.

Pitler TA, Alger BE (1992) Cholinergic excitation of GABAergic interneurons in the rat hippocampal slice. J Physiol (Lond) 450:127-142.

Pitler TA, Alger BE (1994) Depolarization-induced suppression of GABAergic inhibition in rat hippocampal pyramidal cells: $G$ protein involvement in a presynaptic mechanism. Neuron 13:1447-1455.

Robbe D, Kopf M, Remaury A, Bockaert J, Manzoni OJ (2002) Endogenous cannabinoids mediate long-term synaptic depression in the nucleus accumbens. Proc Natl Acad Sci USA 99:8384-8388.

Ronesi J, Gerdeman GL, Lovinger DM (2004) Disruption of eCB release and striatal long-term depression by postsynaptic blockade of eCB membrane transport. J Neurosci 24:1673-1679.

Schupp H, Wong WK, Schnabel W (1987) Mechanistic studies of the photorearrangement of $o$-nitrobenzyl esters. J Photochem 36:85-97.

Sheskin T, Hanus L, Slager J, Vogel Z, Mechoulam R (1997) Structural requirements for binding of anandamide-type compounds to the brain cannabinoid receptor. J Med Chem 40:659-667.

Stella N, Schweitzer P, Piomelli D (1997) A second endogenous cannabinoid that modulates long-term potentiation. Nature 388:773-778.

Stoppini L, Buchs PA, Muller D (1991) A simple method for organotypic cultures of nervous tissue. J Neurosci Methods 37:173-182.

Sugiura T, Waku K (2000) 2-Arachidonylglycerol and the cannabinoid receptors. Chem Phys Lipids 108:89-106.

Sugiura T, Kondo S, Sukagawa A, Nakane S, Shinoda A, Itoh K, Yamashita A, Waku K (1995) 2-Arachidonylglycerol: a possible endogenous cannabinoid receptor ligand in brain. Biochem Biophys Res Commun 215:89-97.

Varma N, Carlson GC, Ledent C, Alger BE (2001) Metabotropic glutamate receptors drive the eCB system in hippocampus. J Neurosci 21:RC188(1-5).

Walker JW, Reid GP, McCray JA, Trentham DR (1988) Photolabile 1-(2nitrophenyl)ethyl phosphate esters of adenine nucleotide analogs. Synthesis and mechanism of photolysis. J Am Chem Soc 110:7170-7177.

Wang J, Zucker RS (2001) Photolysis-induced suppression of inhibition in rat hippocampal CA1 pyramidal neurons. J Physiol (Lond) 533:757-763.

Wei DS, Mei YA, Bagal A, Kao JP, Thompson SM, Tang C-M (2001) Compartmentalized and binary behavior of terminal dendrites in hippocampal pyramidal neurons. Science 293:2272-2275.

Wilson RI, Nicoll RA (2001) Endogenous cannabinoids mediate retrograde signaling at hippocampal synapses. Nature 410:588-592.

Wilson RI, Kunos G, Nicoll RA (2001) Presynaptic specificity of eCB signaling in the hippocampus. Neuron 31:453-462.

Yip RW, Sharma DK, Giasson R, Gravel D (1985) Photochemistry of the $o$-nitrobenzyl system in solution: evidence for singlet-state intramolecular hydrogen abstraction. J Phys Chem 89:5328-5330.

Yip RW, Wen YX, Gravel D, Giasson R, Sharma DK (1991) Photochemistry of the $o$-nitrobenzyl system in solution: identification of the biradical intermediate in the intramolecular rearrangement. J Phys Chem 95:6078-6081.

Zhu QQ, Schnabel W, Schupp H (1987) Formation and decay of nitronic acid in the photorearrangement of $o$-nitrobenzyl esters. J Photochem 39:317-332. 